Portland State University

PDXScholar

1991

\title{
An examination of the long-term effects of authorized training programs on injured workers in the state of Oregon
}

Grace Alice Han

Portland State University

Follow this and additional works at: https://pdxscholar.library.pdx.edu/open_access_etds

Part of the Education Commons, and the Vocational Rehabilitation Counseling Commons Let us know how access to this document benefits you.

\section{Recommended Citation}

Han, Grace Alice, "An examination of the long-term effects of authorized training programs on injured workers in the state of Oregon" (1991). Dissertations and Theses. Paper 4202.

https://doi.org/10.15760/etd.6086

This Thesis is brought to you for free and open access. It has been accepted for inclusion in Dissertations and Theses by an authorized administrator of PDXScholar. Please contact us if we can make this document more accessible: pdxscholar@pdx.edu. 
AN ABSTRACT OF THE THESIS OF Grace Alice Han for the Master of Science in Education presented July 16, 1991.

Title: An Examination of the Long-Term Effects of Authorized Training Programs on Injured workers in the state of oregon.

APPROVED BY THE MEMBERS OF THE THESIS COMMITTEE:

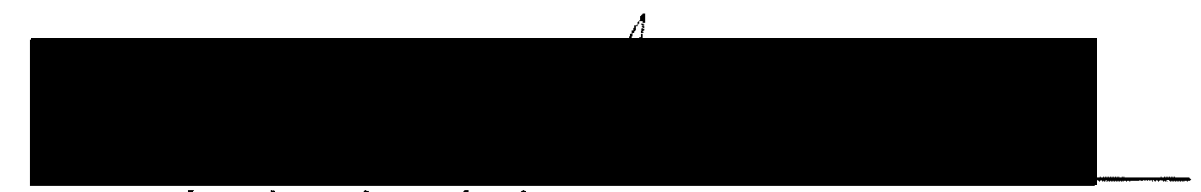

Hanoch Livneh, Chair
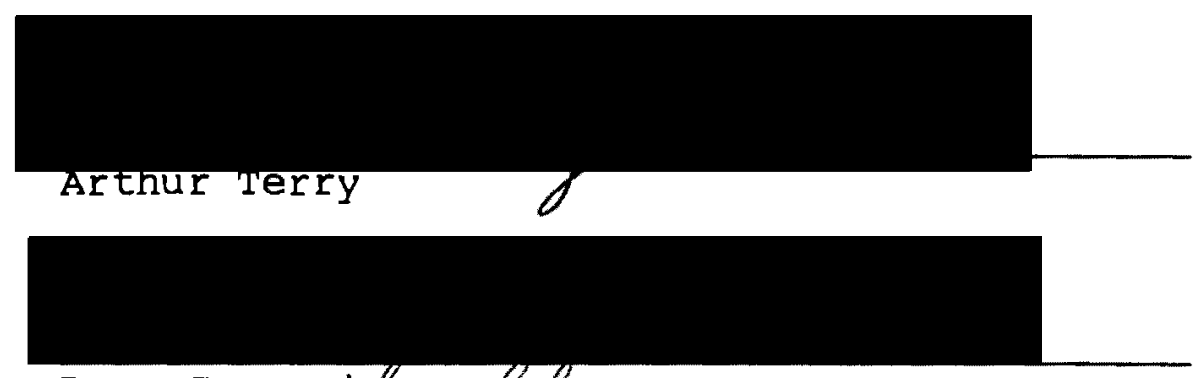

Dave Capuzi

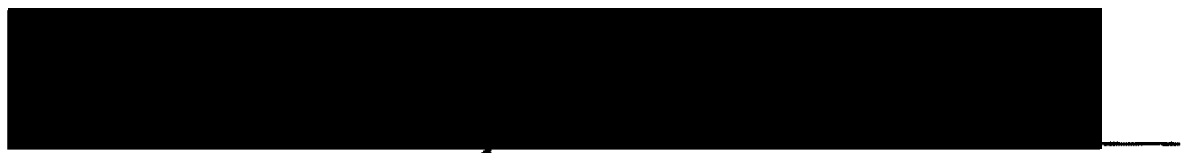

Norman wyers

The worth of rehabilitation programs should be measured in terms of their lasting impact on long-term employment. Vocational rehabilitation programs nationally and internationally appear to be falling short of their goal of long-term gainful employment. competitive employment options for the injured worker appear to have leveled out, the pool of unemployed disabled workers appears to be 
rising, litigation and adversarial relationships are beginning to dominate the rehabilitation process, and costs of vocational rehabilitation are escalating. Increasingly. interest has focused on the long-term influence of vocational rehabilitation, particularly on the costly training programs, and on the employment and economic potential of program recipients.

The present study focused on the current socioeconomic and employment status of those individuals who participated in Authorized Training Programs (ATPS) in 1985 and 1986. It was hypothesized that workers who successfully participated in authorized training programs would be able to maintain long-term gainful employment at or near their wage-at-injury in the field in which they had received ATP training.

The Department of Insurance and Finance, Research and statistic section provided a list of 1,229 injured workers, all of whom had completed authorized training programs during 1985 and 1986. These injured workers became the sample group for the study. The study group was comprised predominantly of blue-collar workers most of whom suffered neck or back strains or sprains.

A total of 618 questionnaires were mailed. An 11.88 return rate was achieved. The responses were examined with respect to geographic, gender and age distribution to assess the extent to which the response group was representative of 
the study group and state population. The response group was found to be representative with respect to age of study group and representative of the geographic distribution of the state population.

The study hypothesis was rejected on the basis of all three criteria of evaluation. The majority of recipients of Authorized Training Programs failed to achieve their preinjury earning capacity, failed to maintain long-term gainful competitive employment and more than two-thirds of the respondents were either unemployed or employed in a field other than the field in which they received training. If rehabilitation counselors desire to remain a viable component within the Workers' Compensation environment, the development of successful training and job placement programs is critical. Based upon survey results, more effort appears to be required to establish rapport with clients, to critically assess. client needs, abilities and interests and to develop a program which adequately reflects the market place. 
AN EXAMINATION OF THE LONG-TERM EFFECTS OF AUTHORIZED TRAINING PROGRAMS ON INJURED WORKERS

IN THE STATE OF OREGON

by

GRACE ALICE HAN

A thesis submitted in partial fulfillment of the requirements for the degree of

\author{
MASTER OF SCIENCE \\ in \\ EDUCATION
}

Portland state University

1991 
TO THE OFFICE OF GRADUATE STUDIES:

The members of the committee approve the thesis of Grace Alice Han presented July 16, 1991.

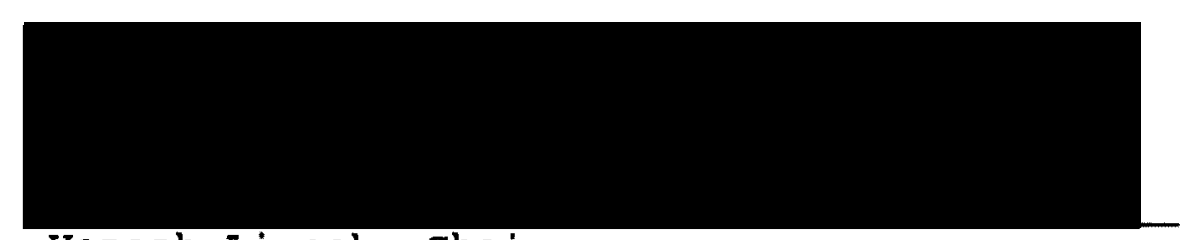

Hanoch Livneh, Chair
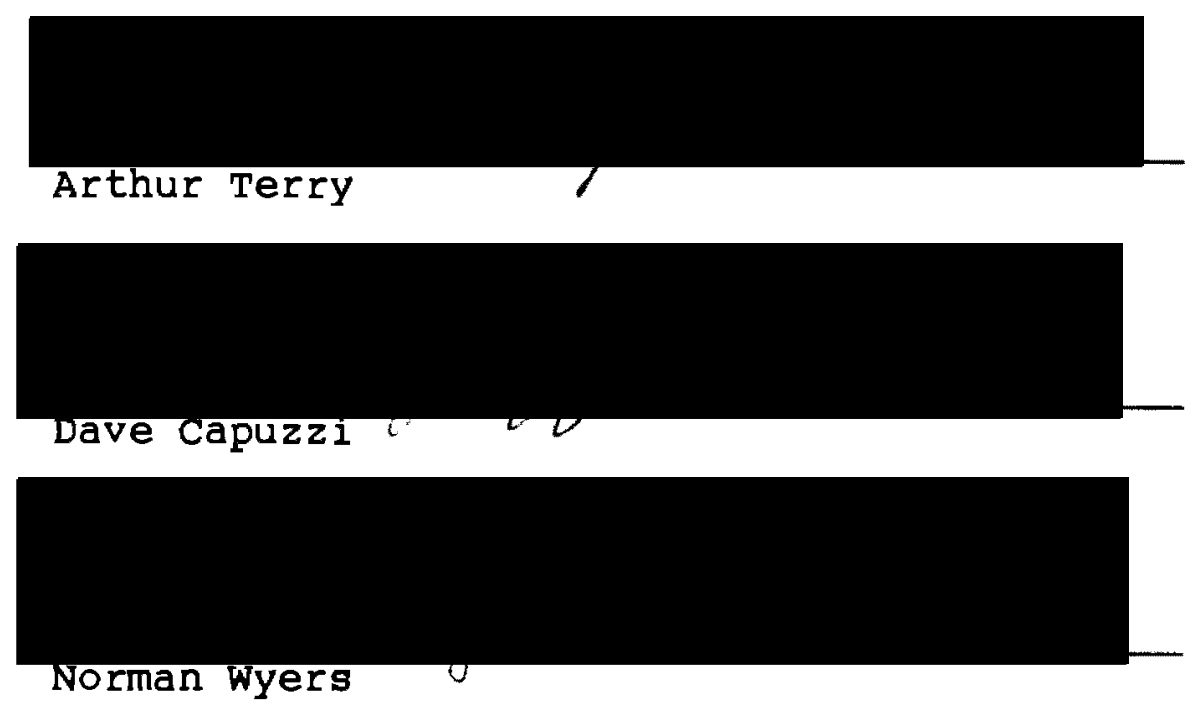

APPROVED :

Robert B. Everhart, Dean, School of Education

C. William Savery, Interim Vtee Provost for Graduate Studies and Research. 
TABLE OF CONTENTS

PAGE

LIST OF TABLES

LIST OF FIGURES

\section{CHAPTER}

I INTRODUCTION . . . . . . . . . . . . . 1

The Workers' Compensation System . . . 1

The Impact of cost Containment on Program Evaluation and Restructuring of the Workers' Compensation System . . . . . 7

II REVIEW OF THE LITERATURE . . . . . . . . . 11

History of Workers' Compensation . . . 11

The Philosophy of Vocational Rehabilitation . . . . . . 16

Barriers to Rehabilitation . . . . 25

Vocational Assistance to Injured Workers in oregon....... 32

III STUDY DESIGN . . . . . . . . . . . 35

Selection of subjects . . . . . . 35

Survey Instrument . . . . . . . . 38

Sample Design . . . . . . . . . 41

Response Rate . . . . . . . . . . 42

Hypothesis . . . . . . . . . . . 46

IV FINDINGS . . . . . . . . . . . . . 49

Wage-at-Injury and Current Wages . . . 49 
Competitive Employment status . . . 51 Training Goal Viability . . . . . 53

V CONCLUSIONS AND RECOMMENDATIONS . . . . . 55 Conclusions . . . . . . . . . 55 Recommendations ......... 63

REFERENCES APPENDICES
A SURVEY INSTRUMENT AND COVER LETTER . . . . 72
B COMPILATION OF RESPONDENT COMMENTS . . . . 76
C WAgE histograms . . . . . . . . . . . . 83
D COMPARISON OF TRAINING TO JOB IN WHICH RESPONDENTS ARE CURRENTLY ENGAGED • • 86 E LIST OF JOBS IN WHICH RESPONDENTS ARE

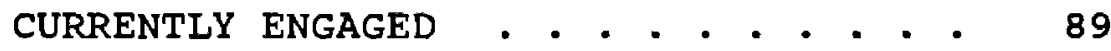




\section{LIST OF TABLES}

TABLE

PAGE

I Employment, Disabling Claims and Claim Rates Oregon $1980-1990$. . . . . . . . 6

II Nature of Injury or Illness . . . . . . 37

III Occupation at Injury . . . . . . . . . 40

IV Standard Industrial Classification (SIC) . 40

V Classification of Survey Responses . . . . 43

VI $\quad t$-Test Results of Response Group and Study

Group for Age Distribution . . . . . 48

VII Means, standard Deviations, and t-Test

Results for Adjusted Wage, Last/

Current Wage and Wage-at-Injury . .

VIII Profile of Respondents Based upon

Employment status . . . . . . . .

IX Profile of Respondents Based on Goal

Viability . . . . . . . . . . 54

$\mathrm{X}$ Summary Profiles Based on Goal Viability . 54

XI Profile of Workers Employed in Training

Field . . . . . . . . . . . 


\section{LIST OF FIGURES}

FIGURE

PAGE

1. Classification of Injury by Body Part . . . 36

2. Age Distribution of the study Group. . . . 39

3. Comparison of Response Group and state Population Geographic Distribution . . . 44

4. Comparison of Response Group Age Distribution and Sample Group Projected Age Distribution . . . . . . . . . 47

5. Shift in Occupational classification Preand Post-Injury . . . . . . . . . . 
CHAPTER I

INTRODUCTION

THE WORKERS' COMPENSATION SYSTEM

Every American is in some way touched or affected by a pervasive no-fault insurance mechanism known as workers' Compensation Insurance. Whether as a small businessman, a member of a large, multi-national company, or simply a consumer, some aspect of Workers' Compensation affects everyone either in terms of increased costs of goods and services or in terms of the increased cost of doing business. If injured on the job, the Workers' Compensation system becomes one's only recourse for mitigation of damages. Workers are compensated for disabling injuries in three ways: disability income payments, payment of injury-related medical costs and, when appropriate, provision of vocational rehabilitation services.

\section{National Workers' Compensation: Claims and Costs}

Shrey (1990) defines the scope of occupational disease, industrial injury and disability in the workplace in terms of its dollar cost. In 1981, the national cost of disability payments (time loss) and health care services for injured workers was estimated to be $\$ 184.6$ billion. The cost 
through the 1980 s has risen at a rate of $16 \%$ per year while the benefits to workers have held constant. Currently the rising cost of medical services is driving the increase in the cost of Workers' Compensation (Thompson, 1990). In 1985, Shrey (1990) estimated the cost of Workers' Compensation to the employers to be about $\$ 30$ billion.

Workers' Compensation premium costs vary by type of occupation and history of accepted disabling claims. Employers in hazardous occupations may pay premiums which run in excess of $10 \%$ of payroll (Thompson, 1990). Average employer costs are not as high:

Nationwide, costs as a proportion of payroll subject to workers' compensation rose to a record 1.98 percent in 1986 , the most recent figure. Some experts foresee workers' compensation premiums absorbing 3 to 5 percent of payroll in the next five years (Thompson, 1990, p. 20).

From the perspective of the human cost, Hester (1990a) estimates that approximately 500,000 workers become seriously disabled each year to the extent that they cannot return to work for prolonged periods of time. Based upon the reported age distribution of disabled individuals in the Social Security Disability Insurance system and on the age distribution of those collecting the Long-term Disability, Hester (1990a) contends that there is a direct relationship between age and disability. As there is a demographic trend toward an aging America, Hester (1990a) concludes there will be a dramatic increase in the disabled worker over the next 3 decades: 
The number of physically and cognitively impaired workers in the system will increase from 2,191,000 in 1985 to $3,297,000$ in 2020. This is an increase of 50.58 (p. 11).

\section{oregon Workers' Compensation: Claims and costs}

According to Manley (1991), in oregon there were approximately 1,254,400 Workers'-Compensation-covered employees in 1990. Among those workers there were 35,857 accepted disabling claims, representing a claims rate of 2.98 (Manley, 1991). For a direct comparison of disabling claims and earned premiums, 1988 figures must be used as premium breakdown figures are not yet available for years subsequent to 1988. In 1988, there were 1,161,100 Workers'-Compensationcovered employees and 43,660 disabling claims, representing a $3.8 \%$ claims rate (Oregon Department of Insurance and Finance, 1990). Earned premiums totaled $\$ 722.7$ million (Manley, 1991). Direct benefits to disabled workers consumed $45.2 \%$ of premiums collected; indirect benefits (medical, rehabilitation services and claimant attorney fees) consumed 34.38 of premiums collected; insurer overhead consumed 20.58 of premiums collected (Manley, 1991).

Putting Oregon's cost in perspective, Oregon's compensation premiums rank eighth highest in the nation on a per capita basis. In 1989 , oregon business expended almost $\$ 1$ billion in premiums although the state represents only $1 \%$ of the nation's population and Gross National Product (Beauchamp, 1990). If one compares Shrey's (1990) 1985 
national $\$ 30$ billion premium figure to oregon's comparative population of 18 , the expected premium, rather than approaching $\$ 1$ billion would be expected to be about $\$ 300$ million. While premiums are the eighth highest in the nation, based on 1988 law, Oregon ranks ninth nationally in maximum weekly benefit (MWB) as a percentage of the state's average weekly wage (WW ) at $\$ 388.99$ and $108 \%$ respectively.

High premium costs can drive employers out of business or out of the state. According to Thompson (1990) cost disparities between states become problematic as states fear the fleeing of employers to lower-cost states. The effect on a state's economy can be crippling. Oregon's Governor Goldschmidt contended that the high cost of Workers' Compensation was keeping business out of the state (Beauchamp, 1990) .

\section{oregon Trends}

Driven by Governor Goldschmidt's desire to improve the climate for business in the state of oregon, the Workers' Compensation system in oregon was completely overhauled in 1990 in order to reduce cost:

The law commits oregon to prosecute health care fraud, police safety rules more closely, review chiropractic invoices and set up health maintenance-type organizations to control the costs of treating injured workers. The law also restricts lawsuits over workers' compensation by stressing arbitration and limiting appeals. The yearly cost of workers' compensation premiums should drop as much as 20\%, or $\$ 200 \mathrm{M}$ (Beauchamp, 1990, p. 261). 
The 1991-2 oregon Blue Book reflects the re-orientation in the direction of workers' compensation:

Major workers' compensation reforms made by a special session of the Legislature in May 1990 emphasize the importance of programs administered by the Department of Insurance and Finance -preventing occupational injuries and helping injured workers return to their jobs. This will not only help reduce oregon's workers' compensation rates, but also will contribute to the state's economic vitality.

The Department was created by the 1987 Legislature combining the Workers' Compensation Department with parts of the former Department of Commerce.

The merger of these agencies reflects the philosophy that the best way to reduce workers' compensation rates in oregon is to prevent occupational injuries and illnesses. This merger places accountability for workers' compensation benefits and premium rates in one agency and improves state government's ability to control programs and costs (Keisling, 1991-92, pp. 85-86).

This cost-containment environment is reflected in a dramatic shift in the rate of accepted disabling claims over the last decade (Table I). Other than the severe recession years of 1981 and 1982 , the claims rate had remained fairly steady. In 1989 and 1990, however, there was a rather dramatic drop in the rate of accepted disabling claims. While the total number of workers'-compensation-covered workers was at an all time high, the number of accepted disabled claims was lower than at any time since 1984. According to Manley (1991), the drop in the disabling claims rate is driven by a much higher denial rate by state insurance vendors (25\% to $30 \%$ higher), a change in occupation 
TABLE I

EMPIOYMENT, DISABLING CLAIMS AND CLAIM RATES OREGON 1980 - 1990

\begin{tabular}{||c|r|r|r||}
\hline \multicolumn{1}{||}{} & & \multicolumn{2}{|c||}{ DISABLING } \\
\hline YEAR & EMPLOYMENT $^{1}$ & NUMBER & RATE $^{2}$ \\
\hline 1980 & $1,050,800$ & 44,930 & 4.3 \\
1981 & $1,026,200$ & 37,498 & 3.7 \\
1982 & 968,700 & 31,535 & 3.3 \\
1983 & 973,900 & 34,037 & 3.5 \\
1984 & $1,013,700$ & 37,702 & 3.7 \\
1985 & $1,034,600$ & 38,808 & 3.8 \\
1986 & $1,064,000$ & 40,157 & 3.8 \\
1987 & $1,105,200$ & 41,033 & 3.7 \\
1988 & $1,161,100$ & 43,660 & 3.8 \\
1989 & $1,212,000$ & 39,170 & 3.2 \\
1990 & $1,254,400$ & 35,857 & 2.9 \\
\hline
\end{tabular}

1 Employment figures are estimated workers'-compensation-covered employment developed primarily from data supplied by the state of oregon Employment Division. Figures represent annual average employment.

2 claims rates represent the number of claims per 100 workers. Disabling claims include fatalities.

Source: Manley, 1991. 
patterns (a shift away from lumber), and the institution and enforcement of more effective safety procedures.

The extent and type of rehabilitation services currently offered to injured workers in oregon have been effected by the cost-containment atmosphere surrounding Workers' Compensation. The scope of clients currently served by vocational service providers is significantly below levels experienced in the mid-1980s.

THE IMPACT OF COST CONTAINMENT ON PROGRAM EVALUATION AND RESTRUCTURING OF THE WORKERS' COMPENSATION SYSTEM

The trend toward management of soaring costs associated with Workers' Compensation systems is international in scope. Canadians appear to be having many of the same difficulties in managing the complex Workers' Compensation system as the United States.

There is a growing awareness among members of the business community that the Workers' Compensation system is in a mess, having strayed miles from its original concept. And the problems affect all of us as the costly system deteriorates into an openended private welfare system, which you and I eventually pay for indirectly. We pay because skyrocketing premiums are passed along in the cost of goods and services wherever possible. . . .

No one quarrels with the responsibility of society and business to look after injured workers. It is to be hoped that the system provides an incentive for employers to provide safe work conditions. But a system that overpays victims or in other ways hands out money indiscriminately is a system that injures society and business alike (Francis, 1989, p. 11). 
Cost Effectiveness of Vocational Rehabilitation Programs

The issue of vocational rehabilitation has become a pressing concern throughout the United States, as well as, internationally. The state of Maine noted in a 1988 Workers' Compensation Commission (WCC) report that Washington, Colorado, Oregon and Minnesota, as a result of higher costs, are changing, limiting or eliminating mandatory vocational rehabilitation. Alaska, despite a new law, is experiencing ineffective translation of the language of the law into servicing of their injured population (Jackson, 1984). The wCC study in Newfoundland and Labrador in 1987 (Downton, Felt \& House, 1987) found an unemployment rate of 52.78 among former rehabilitation program participants.

One hypothesis to account for these withdrawals from mandatory rehabilitation is that rehabilitation involves... an added expense. At a time when loss ratios are increasing, that is especially unwelcome. The issue then is whether there are any benefits to accompany these increased costs (Berkowitz \& Berkowitz, 1991, p. 193).

Increasingly, interest has focused on the long-term influence of vocational rehabilitation, particularly on the costly training programs, and on the employment and economic potential of program recipients. It was emphasized in a study of rehabilitation programs in Labrador that, ". . the ultimate test of rehabilitation programs is their longterm impact on continued employment" (Downton, et al., 1987, p. 123). Vocational rehabilitation programs nationally and internationally appear to be falling short of the goal of 
long-term, gainful employment. California among other states, is limiting the use of training as a viable rehabilitation alternative:

Costs and success rates generally are inversely proportional with the least expensive plans offering the greatest opportunity to return the worker to gainful employment. For example, $85 \%$ of the workers who complete modified or alternative work programs, which capitalize on the employee's transferable skills, in fact return to work. By comparison, only $52 \%$ of workers who participate in formal schooling programs find suitable work after completion. . . . The message in these finds seems apparent: make as few changes as possible in the disabled employee's life. . . Other, more complex training cannot match the cost-effectiveness of short-term rehabilitation programs that minimize the upheaval in the worker's environment. In contrast, formal schooling programs are the longest, most expensive and least successful (California WCI, 1983).

The Need for Longitudinal Program Evaluations

The purpose of rehabilitation and rehabilitation law is to restore injured workers to gainful employment while minimizing the economic impact of their disability. The need for the development of longitudinal data to evaluate the effectiveness of training programs, including the determination of economic impact on the injured worker and the continuation of competitive employment over time, has been recognized by many states facing problems similar to those faced by the state of oregon (Downton, et al., 1987; Maine WCC, 1988; Olsheski \& Growick, 1988).

As a 1988 oregon study of training programs points out, the comparative cost of these programs compels greater 
scrutiny and interest: ". . although training cases represent a small fraction of total vocational assistance cases (10\% of all cases closed in 1986), these cases account for over half of all Workers' Compensation vocational rehabilitation costs (56\% for 1986 closures)" (Oregon Department of Insurance and Finance, 1988, p. 1). As escalating costs are jeopardizing the stability of the entire workers' Compensation system, it is essential that available funds are funneled to effective programs.

The present study focused on the current socio-economic and employment status of those individuals who had participated in authorized vocational training programs in 1985 and 1986. The effectiveness of these training programs was evaluated on three criteria: (a) the post-training wage as compared to wage-at-injury, (b) post-training employment status, and (c) training goal viability. 
CHAPTER II

REVIEW OF THE LITERATURE

HISTORY OF WORKERS' COMPENSATION

Through the end of the nineteenth century, workers sustaining permanent disability as the result of a workrelated injury had no formal recourse to compensation. The injury was considered to be a "private matter" between the injured worker and the employer. In order to maintain some type of livelihood, the worker was forced to depend upon the benevolence of the employer. The employer might offer a position such as night watchman. However, most disabled workers were forced to rely upon the charity of their families or became a public charge (Deneen \& Hessellund, 1981). The number of disabled workers more than kept pace with the expansion of industry during the industrial revolution:

Before workers' compensation, injured employees typically were not able to receive any benefits because the courts held that they had voluntarily assumed the risk of hazardous work. Nonetheless, a growing number of employees hurt in industrial accidents sued for damages, forcing employers into costly legal battles (Thompson, 1990, p.22).

As the cost of support of the ever-expanding disabled worker population grew, lawmakers reacted. The first of many state Workers' compensation laws was enacted in 1911: 
The first laws to withstand legal challenge were enacted in 1911, predating all other social or employer-paid programs to assist injured or sick workers, such as Social security, health insurance, and disability insurance (Thompson, 1990, p. 22).

According to Deneen \& Hessellund (1981), the purpose of these laws was to shift the cost of maintaining the disabled worker from society-at-large to the worker who was responsible for the work-related disability. According to Thompson (1990), Workers' Compensation rose as a compromise between labor and management to handle the problems of liability of workplace injury: ". . Workers' Compensation called a truce to.. . bitter skirmishes by creating the nation's first no-fault insurance system" (p. 22) . Workers received guaranteed compensation for injury at work (nominal cash benefits and necessary medical care as required to "cure or relieve" the effects of injury) and employers were sheltered from unlimited liability (Berkowitz \& Berkowitz, 1991). As part of this arrangement, employers agreed to shoulder the cost (Thompson, 1990).

Expansions and extension of benefits to the disabled workers continued with the growth of power and influence of the labor unions. With this growth of influence came increased medical and income-replacement benefits (Deneen \& Hessellund, 1981). By 1920, all but eight states had Workers' Compensation laws (Thompson, 1990).

Although the early statutes did not specifically mention vocational rehabilitation, New Jersey's law did require 
coordination with the state Vocational Rehabilitation Commission in cases involving permanent and total disability. The establishment of a close relationship between other Workers' Compensation benefits and vocational rehabilitation was, therefore, established from the very early days (Berkowitz \& Berkowitz, 1991).

Over the years, however, the compensation payments fell far below rising wages. By the 1960s, inflation-adjusted compensation was lower than in the 1940s. As a result of eroding effectiveness, Congress created a National Commission on State Workmen's Compensation Laws in 1970. The 1972 report (cited in Berkowitz \& Berkowitz, 1991, p. 188) concluded that state laws were in general "inadequate and inequitable." Most of the critical recommendations of the Commission centered around raising benefits and broadening coverage. One recommendation tied short-term disability payments to the states' average weekly wage, a system which is still widely used. Most states, rather than waiting for mandated changes and intervention from Congress, reacted to the "critical" recommendations (Thompson, 1990).

The commission also addressed rehabilitation issues. The Commission characterized current rehabilitation efforts as, "ineffective" (Berkowitz \& Berkowitz, 1991). The Commission developed a proposed solution which involved the creation of medical-rehabilitation divisions within the state Workers' Compensation agencies: 
1. We recommend that the medical-rehabilitation division be given the specific responsibility of assuring that every worker who could benefit from vocational rehabilitation services be offered these services.

2. We also recommend that the employer pay all costs of vocational rehabilitation necessary to return a worker to suitable employment, authorized by the workmen's compensation agency.

3. We recommend that the workmen's compensation agency be authorized to provide special maintenance benefits for a worker during the period of his rehabilitation. The maintenance benefits would be in addition to the worker's other benefits (Berkowitz \& Berkowitz, 1991, p. 188).

other recommendations of the Commission such as equalizing benefits among the states were introduced but never labeled as "critical" and were consequently not universally adopted by the states (Berkowitz \& Berkowitz, 1991).

In a pioneering move, California added mandatory vocational rehabilitation to their Workers' Compensation statute in 1974. Employees retained the right to deny vocational rehabilitation services as well as to determine the timing of the rehabilitation. States such as California, Maine, Alaska, Minnesota and Colorado, which adopted the concept of mandatory vocational rehabilitation for their injured workers, became the catalyst for the expansion of the private vocational rehabilitation sector (Berkowitz \& Berkowitz, 1991) •

Minnesota has also innovatively moved in a different direction. A two-tiered benefit system was developed to encourage early return to work. No other states, however, 
have followed the lead despite the fact that the law has withstood court challenges (Berkowitz \& Berkowitz, 1991).

\section{Recent Trends in Workers' Compensation Rehabilitation}

In more recent years there has been a retreat from mandatory vocational rehabilitation. Laws in Colorado, Washington and Florida have been changed to eliminate mandatory rehabilitation (Berkowitz \& Berkowitz, 1991). Still other states are instituting studies to define the needs, issues and problems associated with providing rehabilitation services to injured workers (Tinsley, 1988).

A recent report released by a California Senate committee advocated a more comprehensive state mandated system of compensation that would pay benefits for illness or injury regardless of the place of occurrence. This more comprehensive plan would scrap the traditional Workers' Compensation approach. The program would be funded by employers and employees alike. With employees paying into the program, the question of whether the no-fault provisions which have shielded employers from law suits would continue to stand is problematic. Rehabilitation would again be combined under the traditional state run Vocational Rehabilitation umbrella. This report is consistent with the recent move toward more comprehensive health care plans (Thompson, 1990). 
THE PHILOSOPHY OF VOCATIONAL REHABILITATION

Theoretically and Empirically Developed Rehabilitation Models

Akabas' approach to rehabilitation is based upon the belief that most workers inherently wish to return to some sort of employment. According to Akabas (1990), studies indicate that individuals prefer to continue to work even if they were to be offered an adequate living to meet their living expenses. Akabas (1990) further contends that, "young persons are more likely than are older persons to express their continuing interest in work even when assured of a comfortable living without it" (p. xvii). Akabas (1990) citing G. Friedman (1986), contended that extended unemployment may be a threat to mental health. Akabas (1990) also cites a 1986 Louis Harris Survey which, ". . confirmed that the vast majority of disabled respondents would prefer to work" (p. xviii).

According to Akabas (1990), this inherent interest in work is reinforced by the shift in Americans' expectations with regard to the workplace:

In short, there remains a widespread acceptance of the traditional work ethic, but there are now parallel expectations that work will be interesting, meaningful, and even self-actualizing; that the worker will feel secure in the workplace as a result of clear information and truly safe working conditions; and that working will not usurp the time and energy needed for such other important aspects of life as leisure, family and education. In addition, there are the expectations that less time will be spent at work and that the work will 
be organized in a way that permits creativity during working hours (p. xix).

This image of the workplace appears consistent with work environments where the more paternalistic Japanese management model has been adopted.

There are two opposing views of the affect of a changing economic environment on disabled workers. One view postulates that in the coming decade those born during the "baby bust" will live in an environment of worker shortage. Therefore, people with disabilities will be able to capitalize on this worker shortage. The opposing view contends that with technological advances, jobs will be displaced or eliminated, service jobs will become increasingly less-remunerative, and the marginal workers (including those with disabilities), ". . will become second-class citizens in a two-tiered society" (Akabas, 1990, p. xx).

Akabas adopted Goodwin's (1972) model of predicting an individual's response to work:

1. attitude: how much the person likes or dislikes work

2. goal: what ends the person hopes to achieve through work

3. belief: what expectation the person has of achieving those goals through work or some alternative means

4. intentions: how the person decides to get required money (i.e., through work or other means) ( $p . x x)$.

Based upon this model, disabled workers require success in return-to-work efforts. Fears of success or experiences of failure in return-to-work efforts may result in searches for 
alternative methods of support (attempts to achieve a ruling of Permanent Total Disability or attempts to gain Social Security Disability Insurance) (Akabas, 1990). Events or situations which might influence injured worker behavior would include medical prognosis, alternative income options, employment alternatives (perceived or real) and availability of services and a support system (Akabas, 1990).

Akabas (1990) offered two models which ". . seem to apply to the situation faced by the newly impaired worker (p. $x x) "$-- the medicolegal model and the biopsychosocial model. Akabas (1990) characterizes the medicolegal model as tending to negatively impact the ultimate rehabilitation of workers and the biopsychosocial model providing a more positive approach in rehabilitation of workers.

In the medicolegal model the medical and psychological records and physician's recommendations drive the case. When the objective medical findings no longer correspond to the level of functioning demonstrated by the worker, the case reverts to litigation and administrative hearings to define the amount of permanent disability and grant financial benefits based upon a defined level of disability. Akabas (1990) contends that, consistent with Goodwin's model, workers, once defined as disabled, become convinced of their disability and tend to drop out of the workplace, becoming permanently and totally disabled. 
The biopsychosocial model redefines the relationships among the claimant-worker, labor and management representatives, and the medical service personnel. Paramount in this model is the maintenance of an ongoing worker relationship to the workplace. The model reinforces the importance of work in the overall psychological and physical well-being of the worker. From outset of injury, the worker is reassured that he or she will maintain a position in the workplace. The employer becomes an integral part of the rehabilitation process (Akabas, 1990). Consistent with Wright's (1983) belief in the principle of comanagement, the worker is an equal player in the rehabilitation process. This model appears to be the "theoretical" underpinning of the disability management approach currently being adopted by many larger employers.

Vocational Rehabilitation in the Workers' Compensation Environment

Hester (1990b) contrasts the goal of vocational rehabilitation for injured workers with the goal for developmentally disabled individuals. According to Hester (1990b), the objective of rehabilitation developed by the National Council on Rehabilitation in 1942 is, ". . . to bring persons with disabilities to the fullest physical, mental, social, vocational, and economic functioning that they are capable of attaining" (p. 215). In contrast, the objective of rehabilitation of injured workers under the Workers' 
Compensation system is,". . to return disabled workers as close to their predisability medical and vocational function as is reasonably attainable" (Hester, 1990b, p. 215).

According to Hester (1990b), the steps involved in correct vocational rehabilitation of injured workers are: (1) to assess feasibility of employment with the employerat-injury, and (2) to assess transferable skills and attempt direct employment. only after other types of services are found to be inadequate to return the injured worker to gainful employment are training programs considered.

Accordingly, the role of the vocational rehabilitation counselor is to ". . outline a program for safe and appropriate work return" (Demore-Tabore \& Cohen-siskind, 1990, p. 47). The process of vocational rehabilitation is a multistep process involving interaction with a multi-disciplinary team (including the employer-at-injury, the worker's attorney, the insurance company and the worker's union). As Deneen and Hessellund (1981) point out, the various members of the multi-disciplinary team have conflicting interests which must be balanced.

The impaired worker may eventually return to modified work at the employer-at-injury or undergo a process of evaluation and training which ultimately leads to placement in a new field with a new employer (Demore-Tabore \& Cohensiskind, 1990). Those authors offer a vocational rehabilitation model, the elements of which are probably fairly 
consistent across the country. The steps of their model include:

Step 1: Clinical Assessment. The assessment includes all of the following elements: financial impact, pre-injury work history, duration of time out of work since the injury, the family support system, level of education achieved, employer attitude toward rehiring the worker, current legal situation (appeals, applications for disability), and union policies.

Step 2: The Vocational Rehabilitation Plan. The plan is developed as quickly as possible following the clinical Assessment. Medical and neuropsychological documentation are included. The plan includes a vocational prognosis, short- and long-term vocational goals and recommendations. The worker is a participant in this process.

Step 3: Career Counseling. Testing and transferable skills analysis are an integral part of this process. The authors perceive this step is one in which the impact of the injury is integrated into a worker-counselor comanaged planning phase:

At the very least, the career counseling process allows the vocational counselor and injured worker time to review the person's physical, cognitive, and behavioral strengths and weaknesses as they relate to vocational planning and to assist the client in developing insight into the impact of these strengths and weaknesses on vocational options (Demore-Tabore and Cohen-siskind, 1990, p. 55). 
Step 4: Vocational Goal setting. Goal setting includes an assessment of employer-at-injury options, worksite modifications, if necessary, or the development of a new vocational direction.

Step 5: Job-Seeking skills Training. The counselor assesses the needs of the client and provides help as appropriate. Such training may include help in identifying appropriate job openings, resume writing, and job interview skills.

Step 6: Job Development and Job Placement. Job search is comanaged. The client and counselor are aggressively involved in all phases of the job search. Following each job interview, the counselor evaluates the interview with the client after receiving feedback from the employer offering the interview. Such feedback sessions are valuable aids in further refining job-seeking skills.

Step 7: Work Adjustment Counseling. Follow-up counseling varies from state to state. The amount and type of follow-up appropriate to the situation are, to a large degree, driven by the severity of the disability.

New Trends in Employer-Driven Rehabilitation

The trend toward cost containment has led to the development of greater employer interest in all aspects of Workers' Compensation. Employers are searching for new ways to manage their compensation program to decrease overall cost. Shrey (1990) feels that there are currently several barriers 
to effective employer intervention in compensation management. These include relinquishing control to others, lack of employer expertise, and ineffective or inefficient programs.

Employers have traditionally relinguished control and responsibility for industrial injury and disability to a third carrier (insurance company, vocational rehabilitation organization, medical professionals). As a result, care has become fragmented and the employer (who is footing the bill) is rarely a member of the team. As Shrey (1990) also points out, conflicting goals impact this process: ". . furthermore, there are complex and conflicting relationships between employer goals, resources, and expectations; the needs and self-interests of the employee, and the services available in the community" (p. 91).

Employers do not have trained personnel and do not know how to access services available in the community. Supervisors are not trained in addressing the psychological and social needs of impaired workers. Few employers have the mechanisms in place to monitor disabled workers and initiate treatment and back-to-work transition programs (Shrey, 1990) .

The current system is beset by ineffective and inefficient programs. Rehabilitation plans are not always developed for employees who could benefit from those plans. Many times there is a lengthy delay in referring injured workers 
to rehabilitation services. Employees are not always equal partners in the development of their treatment plan (Shrey, 1990) .

In consequence of the rising costs and employer perceptions of inadequacy of the present system, a mechanism known as disability management has developed to address employer concerns. Shrey (1990) describes the basic principles of disability management as follows:

1. It is an active process

2. It is a process that enables the employer both to exert control and to assume responsibility as a proactive decision maker, planner, and coordinator of interventions and services.

3. It promotes disability prevention strategies, rehabilitation treatment concepts, and safe work return programs designed to control the personal and economic costs of workplace injury and disability (p. 93).

Shrey (1990) further argues that:

The overall disability management process for impaired workers requires close monitoring of all activities related to the worker's medical treatment, motivation for work return, and secondary barriers to work return. Typical work return obstacles are psychological problems, inability to manage pain effectively, improper use of medications, marriage and family problems, negative worker attitudes, past claims settlements, labor relations problems, and unresolved legal issues (p. 93).

Shrey (1990) believes that disability management is a role that large employers are able and should develop to service their workers. The role of the Vocational Rehabilitation organization (VRO) may, in the future, be confined to 
the needs of the small business with limited opportunities for workplace modification.

As employers take the more active role of disability managers, increased health care and rehabilitation service accountability will result. It is conceivable that the employer of the future will no longer rely on external third-party providers to manage the medical, vocational, and psychosocial aspects of worker injury and disability. Conversely, health care and rehabilitation providers will look to industry for guidance in revitalizing, modifying, and delivering services that are responsive to the medical, legal, vocational, and labor relations problems faced by employers and their disabled workers (Shrey, 1990, p. 102).

\section{BARRIERS TO REHABILITATION}

According to Hester (1990b), 36\% of disabled workers reach the age of 65 without ever re-entering the labor market. Another $8 \%$ die before the age of 65 but live an average of 6.4 years after leaving employment. Hester (1990b) contends that although there are some workers who are too disabled to work, for others: ". . . it is a matter of the amount of pain that a person will tolerate in order to be productive. For example, entrepreneurs with progressive disabilities remain productive 4 years longer than do employees" (p. 205). Sources of disincentives to return to competitive employment are entrenched in the current Workers' Compensation system. They include Social security Disability Insurance (SSDI), employer attitudes, rehabilitation agencies, and the worker (Hester, 1990b). 
The Social Security Disability Insurance (SSDI) Program

Within the Social Security Disability Insurance program the most serious problem (disincentive) surrounds the issue of significant gainful employment levels and the discontinuance of benefits. Workers are unwilling to consider employment options if guaranteed income is at risk.

The empirically developed Menninger Return to work scale indicates that when a person is allowed SSDI benefits that person's chances of returning to work drop from $46 \%$ to $17 \%$. Trietel found that only about $7 \%$ of 1972 SSDI beneficiaries returned to work by 3 years later. This is the lowest return-to-work rate among the beneficiaries of any disability support system (Hester, 1990b, p. 207).

Beyond the issue of income risk is the issue of self-perception. Hester $(1990 \mathrm{~b})$ contends that the SSDI approval process transforms the self-concept of the worker:

Once a former worker has successfully internalized the feeling of total incapacity, it becomes extremely difficult for that worker to consider vocational rehabilitation seriously (p. 208).

\section{The Current Workers' Compensation system}

Hester (1990b) contends that the current state of Workers' Compensation offers little in the way of incentives for quick return to work if the possibility of litigation can improve the economic settlement of the injured worker:

A combination of public and private sector programs, the workers' compensation program possibly represents the worst of both sectors. The intent of the original workers' compensation legislation was to avoid litigation by establishing a framework in which a worker could be justly compensated for a work-related injury. Neither legislation nor litigation has provided a method of managing 
the separate and often conflicting interests of all parties, however (Hester, 1990b, p. 210).

Hester (1990b) remarks that the only positive off-shoot of the congressionally mandated employer funding of Workers' Compensation programs has been a motivation to contain costs by ensuring safety on the job: ". . according to the National safety council, the number of workers killed on the job decreased from $37 / 100,000$ in 1933 to $18 / 100,000$ in 1969, a $51 \%$ decrease" (p. 210). Furthermore, employer apathy, Hester (1990b) asserts, has resulted in the contentious and litigious system now in effect. Greater employer participation in the form of disability management may be the key to getting Workers' Compensation under control again.

\section{Long-Term Disability Insurance}

A disincentive not generally considered is that of Long-Term Disability Insurance. According to Hester (1990b), a worldwide study found that when disability insurance payments approach $60 \%$ to $70 \%$ of the working wage, a substantial portion of beneficiaries withdrew entirely from the labor market. Attempts by insurance carriers to contain costs through off-sets (mandated off-setting or reducing of their payments by the amount which is being paid by other disability programs) have also created disincentives. Many insurance carriers are withholding payment until the claimant applies for SSDI, the program with the lowest return-towork rate of all disability programs. 


\section{Employers}

Apathetic and shortsighted employers have indirectly caused many of the problems inherent in the current Workers' Compensation system. However, management style is changing. The strong antipaternalistic and passive attitude is being replaced by the Japanese paternalistic management style. Hester (1990b) discovered in employer surveys that although more that $77 \%$ of employers believe that not all injured workers should be guaranteed a job, the same high percentage believe that more than just disability benefits should be provided. Currently, $81 \%$ of employers believe that return to work of injured employees raises the morale of other workers (Hester, 1990b).

Hester (1990b) found that transitional employment (temporary part time or light duty work) is not available in all employer situations. In fact, Hester (1990b) found that $31 \%$ of employers he surveyed did not have light duty work available. Permanent job redefinition was an option that only $26 \%$ of the employers surveyed allowed. These are areas where rehabilitation professionals have room to achieve by working effectively with employers wherever possible to restructure jobs.

Recently, many large employers have opted to selfinsure both Workers' Compensation and long-term disability programs using third-parties to manage the program:

Those in rehabilitation services can help thirdparty administrators to understand the value of 
rehabilitation and return-to-work programs. The emerging competitiveness within the field of disability benefits administration should induce them to listen to ideas that will give them an edge (Hester, 1990b, p. 212).

Hester (1990b) also found that early contact by the employer was essential in the process both to maintain the motivation of the injured worker and to help the employer plan to meet personnel needs of the firm. Early selection and referral of rehabilitation candidates is recently becoming institutionalized in many state programs as the result of empirical evidence and theoretical consistency as to its effectiveness in increasing return-to-work rates (Boschen, 1989; California Workers' Compensation Institute, 1983; Congress of the U.S., Hearings, 1988; Fierro \& Leal, 1988; Jackson, 1984; Maine WCC, 1988).

\section{The Medical Community}

Hester (1990b) believes that the primary care providers can make or break rehabilitation efforts and change the attitude of the vulnerable disabled worker with just a careless choice of words:

Usually, within a few days after surviving a lifethreatening injury or illness, a patient asks when he or she will be able to return to work. Too often the physician answers, "Don't worry about going back to work." Such a comment may be meant to calm the patient, but the result is often just the opposite; furthermore, it can be the beginning of a worker's disability syndrome (Hester, 1990, p. 214).

Furthermore, Hester (1990b) argues that physicians are not always aware of the value of productive activity in 
hastening a patient's recovery. Studies with cardiac patients have found that individuals receiving counseling within 2 weeks of a heart attack returned to work $80 \%$ faster than those in a control group (Hester, 1990b, p. 214). waiting until a patient becomes medically stationary can result in a permanently and totally disabled worker.

The Private Vocational Rehabilitation organization (VRO) Surveys of former rehabilitation clients, counselors and employers reveal a variety of problems with the private Vocational Rehabilitation organizations - the purveyor of choice of vocational rehabilitation services throughout most of the United States. These problems include:

1. Client perception that the relationship between the insurance carriers and the VRO is too close - causing the client to adopt an adversarial attitude toward the vocational counselors (Maine WCC, 1988);

2. Counselor/Client differences in perceptions of goals and program success (Murphy, 1988);

3. Discrepancies between vocational training and actual job success (Wilgosh, 1988);

4. Quick placements, but at the sacrifice of the quality of the placement (Congress of the U.S., Hearings, 1988).

These problems may explain, at least partially, the lower than expected competitive employment placement rate. 
Possible remediation could be accomplished through restructuring the way in which vocational rehabilitation services are offered. A costly recommendation considered vital to the long-term competitive employment of the disabled worker is the development of long-term follow-up services. Such services would include placement services such as job-seeking skills training, career development programs, job clubs, postemployment counseling, job development services and direct interventions with employers (Bordieri, 1986; Botterbusch, 1989; Roessler \& Bolton, 1985). These services, as the California Workers' Compensation Institute (1983) observed, could be offered in conjunction with other state services, thereby spreading (and, perhaps, reducing) cost, and therefore, could be offered to the disabled population at large.

Attempts at intra-agency cooperation have not always been successful. According to Berkowitz \& Berkowitz (1991), the participation of the California Department of Vocational Rehabilitation (DVR) in the Workers' Compensation rehabilitation program was discontinued in 1985. The DVR had little success in conducting the Workers' Compensation activities on a self-supporting, billable hour (emulating the private vocational rehabilitation sector), and the agency found it "frustrating" to submit its plans to the Workers' Compensation agency for review. 


\section{The Worker Profile}

Hester (1990b) believes that return-to-work probability is directly related to the pre-injury level of education, achievement, motivation, drive and occupation level of the disabled worker. Also, less often considered, is the worker's pre-injury concept of disabled individuals. The more useless the worker had perceived individuals with disabilities, the more problems the worker will have accepting himself or herself (Hester, 1990b). The role of the counselor in providing services which will aid in self-acceptance may be crucial to successful vocational rehabilitation.

VOCATIONAL ASSISTANCE TO INJURED WORKERS IN OREGON

Pursuant to the rulemaking authority in ORS 656.726(3) (Workers' Compensation, Administration, 1985), the Director of the Department of Insurance and Finance administers vocational assistance to injured workers through a set of administrative rules, the oregon Administrative Rules, Chapter 436, Vocational Assistance to Injured Workers. constant fluctuations in the rules reflect the dynamic environment of the Workers' Compensation system in oregon.

The scope of vocational rehabilitation services to be provided to injured workers is outlined in oregon Administrative Rules, Chapter 436, Division 120 (Vocational Assistance to Injured Workers, 1988). Injured workers may be 
provided three major types of vocational rehabilitation services: (1) Vocational Evaluation, (2) Direct Employment and (3) Training. An Authorized Training Plan (ATP) is generally offered only to those workers who have the following characteristics: (1) relatively high wage at injury, (2) physical inability to return to their previous employment, and (3) no or limited transferable skills suitable for employment approximating wage-at-injury. The eligibility requirements are outlined in administrative rules governing vocational rehabilitation:

(1) The insurer shall develop a training plan for an eligible worker only when the insurer finds that a direct employment plan is not sufficient for the worker to obtain suitable new employment, other than by reason of the condition of the labor market; and the worker, only with the training provided under section (2), can return to employment which pays a wage significantly closer to the wage at the time of injury. "Significantly closer" may vary depending on several factors, including the worker's wage at injury. OAR 436-120-085 (Vocational Assistance to Injured Workers, 1988)

once training is authorized, a goal is determined by building or expanding on the training, ability, interests and transferable skills which the injured worker already possesses. The authorized training program is generally administered through the referral of the injured worker to a private vocational rehabilitation organization.

The 1988 Longitudinal Training Program study

In 1988, the Department of Insurance and Finance undertook a longitudinal study of vocational rehabilitation 
training cases in 1985 and 1986 pursuant to a requirement of House Bill 2900. The department evaluated the training program "using the yardsticks of return-to-work rates, job, and wages" (Oregon Department of Insurance and Finance, 1988, p. 25). Highlights of the study included the following summary findings:

Workers who completed training during 1985 and 1986 were more likely to return to work than persons in vocational rehabilitation overall. The 1,220 persons in the sample group had a return-towork rate of $61.0 \%$, compared with $54.3 \%$ for rehabilitation cases closing in fiscal year 1985.

At least $82 \%$ of the sample worked at some time after training, but many of them did not remain steadily employed. . . .

The great majority of the group who returned to work went to a new job. Most returned to work in jobs which were related to their training ... (Oregon Department of Insurance and Finance, 1988, p. 25).

In the closing comments of the report, the Department commented on the short period available in which to evaluate the effectiveness of the training programs in terms of worker employment outcome (Oregon Department of Insurance and Finance, 1988).

The current study follows this identical group of workers through the close of 1990 . It was hoped that a study at the end of a five year period would provide added value in improving the programs available for injured workers in the state of oregon. 


\section{CHAPTER III}

STUDY DESIGN

\section{SELECTION OF SUBJECTS}

The Oregon Department of Insurance and Finance, Research and statistic section provided a list of the names and addresses of the 1,229 injured workers who had completed authorized training programs during 1985 and 1986 (Oregon Department of Insurance and Finance, N.D.). These injured workers became the study group for the research project. The 1988 Report to the Oregon Legislature on Workers' Compensation Vocational Rehabilitation Training Cases Completed in 1985 and 1986 (Oregon Department of Insurance and Finance, 1988) outlined pertinent characteristics of the study group.

\section{Injury classification}

Injuries were classified by the part of the workers' bodies affected by the job-related injury (Figure 1) as well as by the nature of the injury or illness (Table II). Workers injured in the region of their trunks, which included the back, hips, abdomen, chest, and shoulders, accounted for approximately $57 \%$ of the study group. Sprains or strains accounted for $60.6 \%$ of all injuries. 
PART OF BODY AFFECTED

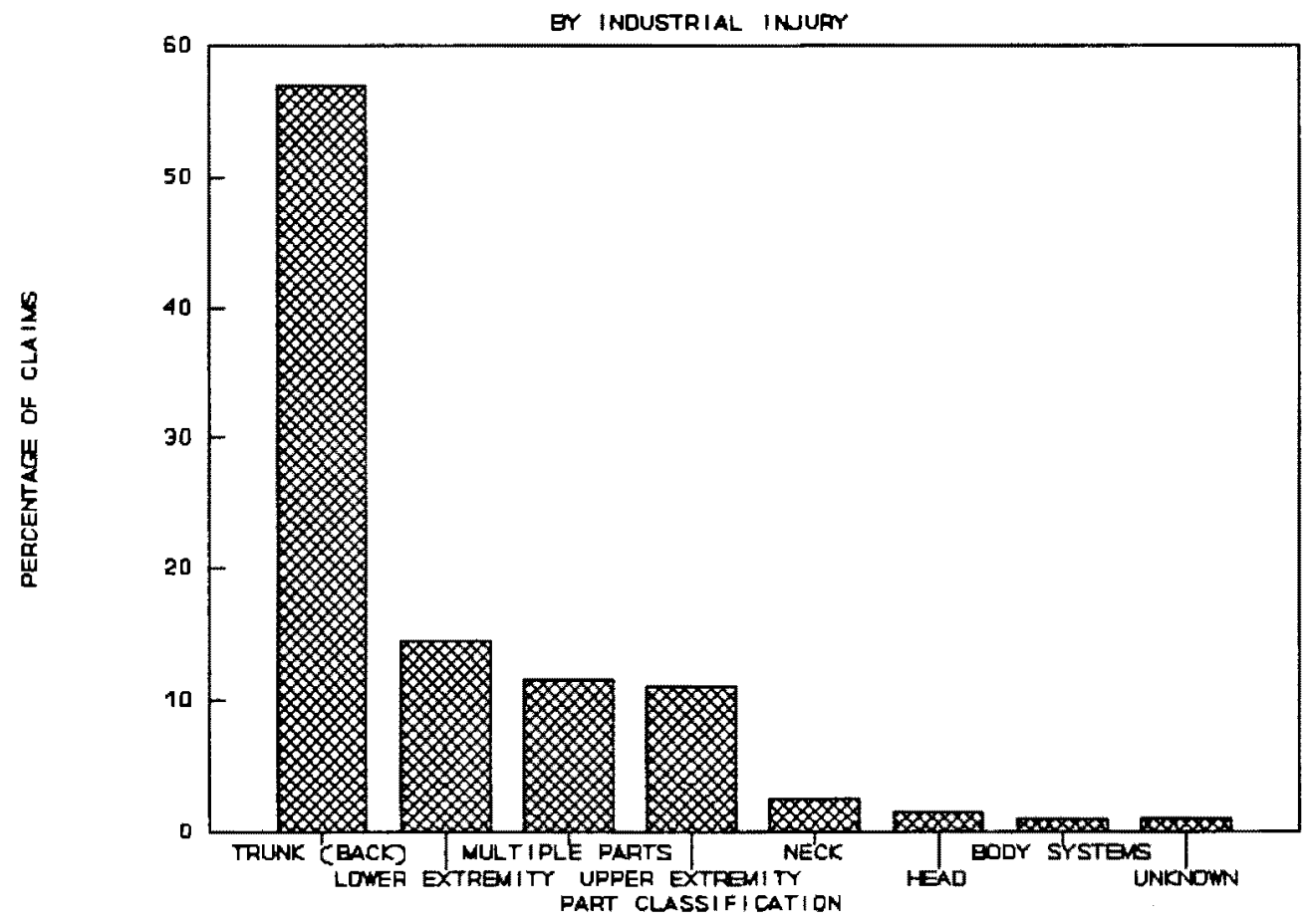

Figure 1. classification of Injury by Body Part. Source: Oregon Department of Insurance \& Finance, 1988, p.7. 
TABLE II

NATURE OF INJURY OR ILLNESS

\begin{tabular}{|l|c|r|}
\hline $\begin{array}{c}\text { Nature of Injury } \\
\text { or Illness }\end{array}$ & $\begin{array}{c}\text { Number of } \\
\text { claims }\end{array}$ & $\begin{array}{c}\text { Percentage } \\
\text { of claims }\end{array}$ \\
\hline Amputation & 10 & .8 \\
Burns (heat) & 6 & .5 \\
Contusion & 88 & 7.2 \\
Cut, puncture & 15 & 1.2 \\
Dermatitis & 2 & .2 \\
Dislocation & 55 & 4.5 \\
Fracture & 92 & 7.5 \\
Hernia & 1 & 3.9 \\
Inflammation & 48 & .3 \\
Poisoning Systemic & 4 & .1 \\
Scratches abrasion & 1 & 60.6 \\
Sprains, Strains & 745 & 2.4 \\
Muliple injuries & 30 & 2.6 \\
Nervous system & 32 & 8.1 \\
Remainder & 100 & 100.0 \\
\hline Total & 1,229 & \\
\hline
\end{tabular}

Source: Oregon Department of Insurance \& Finance, 1988, p. 31 . 
Age and Gender at Injury

The ratio of males to females among the study group members was approximately $3: 1 ; 758$ of the study group was male and 258 female. With regard to age, the age group comprised of individuals from the ages of 25 to 44 constituted nearly $75 \%$ of the study group (Figure 2 ).

\section{Occupational Group at Injury}

The majority $(89.1 \%)$ of workers fell into blue-collar work categories such as Laborers (except Farm), Service Workers, Operators, and Craftsmen (Table III). Most workers in the survey group were engaged in Manufacturing, Construction or service industries (Table IV).

\section{SURVEY INSTRUMENT}

A questionnaire (Appendix A) was sent to each follow-up study participant. The front page of the questionnaire utilized for this study was similar to the device used in the 1988 oregon Department of Insurance and Finance study (Oregon Department of Insurance and Finance, 1988). A personal data section (similar to the device used in the Newfoundland study (Downton, et al., 1987)) was also included on the back page of the survey. It was imperative to add demographic data as information available on individual study group members was confined to names and addresses. Furthermore, information concerning pre- and post-injury education, marital status, number of dependents, mobility 
AGE DISTRIBUTION

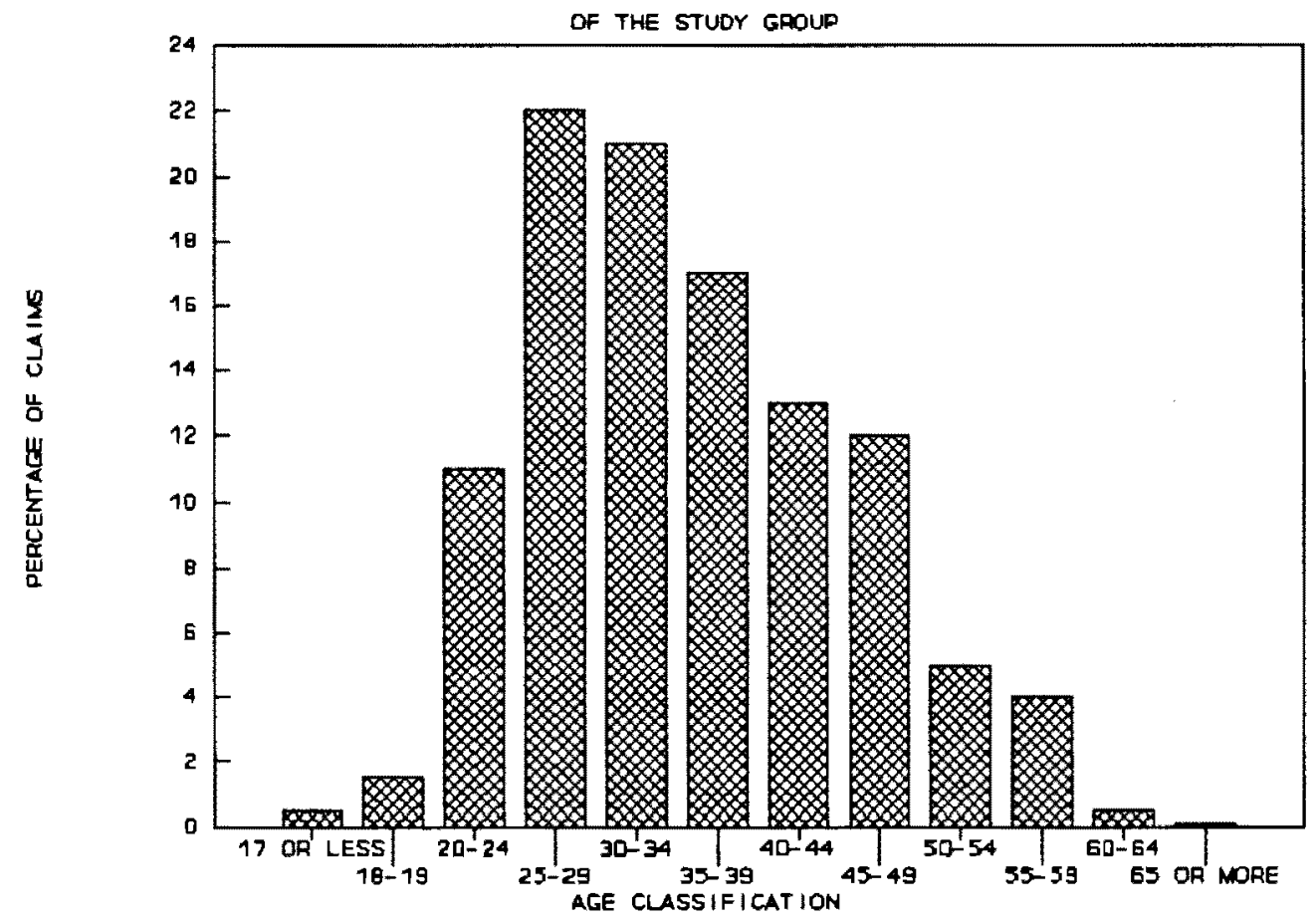

Figure 2. Age Distribution of the study Group. Source: Oregon Department of Insurance \& Finance, 1988 , p. 11 . 
TABLE III

OCCUPATION AT INJURY

\begin{tabular}{||l|c|}
\hline Occupation at Injury & $\begin{array}{c}\text { Study } \\
\text { Percentage }\end{array}$ \\
\hline Laborers, except Farm & 23.2 \\
Service Workers & 16.4 \\
Operatives except Transport & 18.5 \\
Transport Equipment Operators & 10.0 \\
Craftsmen \& Admin. Support & 15.0 \\
Technical \& & 4.5 \\
Farm Workers & 3.3 \\
Sales Occupations & 1.9 \\
Professional \& Managerial & 6.1 \\
Other & 1.2 \\
\hline TOTAL & 100.0 \\
\hline
\end{tabular}

Source: Oregon Department of Insurance \& Finance, 1988, p. 33.

TABLE IV

STANDARD INDUSTRIAL CLASSIFICATION (SIC)

\begin{tabular}{||l|c|}
\hline \multicolumn{1}{|c|}{$\begin{array}{c}\text { Standard Industrial } \\
\text { Classification }\end{array}$} & $\begin{array}{c}\text { Study } \\
\text { Percentage }\end{array}$ \\
\hline Agriculture Forestry Fish & 4.1 \\
Mining & .3 \\
Construction & 13.3 \\
Manufacturing & 41.2 \\
Transportation & 9.0 \\
Wholesale Trade & 5.6 \\
Retail Trade & 12.2 \\
Finance Insurance & .3 \\
Services & 12.9 \\
State/Local Government & 1.2 \\
\hline TOTAL & 100.0 \\
\hline
\end{tabular}

Source: Oregon Department of Insurance \& Finance, 1988, p. 33 . 
and sole-wage earner status could be used to measure the long-term affects of disabling injury on worker lifestyle. The questionnaire used in this study was not assessed as to its degree of reliability and validity as it was adapted from forms used in similar studies in the past (e.g., oregon's 1988 DIF Study and the Newfoundland study). Those field-tested questionnaires appeared to have an acceptable level of content validity.

\section{SAMPLE DESIGN}

To reduce the overall cost of the survey, a random stratified sample of 618 individuals was selected from the total study group $(1,229)$. The study group was stratified by district, county and $z$ ip code. The sample was randomly selected from each county zip code group so as to achieve a sample which was geographically representative of the study group as a whole. As each district in the state has unique economic characteristics, the reflection of the diversity within the sample was considered to be of significance.

\section{Procedure}

The questionnaires were labeled with an observation number so that the responses could be tracked for survey response follow-up purposes only. A cover letter, questionnaire and stamped, self-addressed envelope were mailed to each randomly selected participant. 
The initial mailing was followed-up with post office forwarding and with library telephone books to determine more current addresses of returned questionnaires. If a new address was found, a second mailing of questionnaires to those non-respondents was made. Unsolicited telephone calls from participants receiving the questionnaire were received and questions were answered relative to the purpose of the survey.

\section{RESPONSE RATE}

\section{Total Responses}

of the 618 questionnaires mailed, 73 completed and useable questionnaires were returned. That response represented an $11.8 \%$ return rate. Table $\mathrm{V}$ depicts the status of the survey questionnaires mailed. The responses were examined with respect to geographic distribution, gender and age distribution to assess the extent to which the response group was representative of the study group and state population.

\section{Geographic Distribution of Responses}

The response rate was lower than expected, but a plotting of the geographic distribution of responses and the geographic distribution of the general state population on an XY graph (Figure 3) showed what appeared to be a strong correlation. Using regression analysis Pearson's Coefficient of Correlation ( $r$ ) was calculated to be .92 . 


\section{TABLE V}

CLASSIFICATION OF SURVEY RESPONSES

\begin{tabular}{|l|c|c|}
\hline \multicolumn{1}{|c|}{ Result of Mailing } & $\begin{array}{c}\text { Number of } \\
\text { Questionnaires }\end{array}$ & $\begin{array}{c}\text { Percentage of } \\
\text { Questionnaires }\end{array}$ \\
\hline Moved/Unable to Locate & 224 & $36.3 \%$ \\
Refused/No response & 321 & $51.9 \%$ \\
Responded & 73 & $11.8 \%$ \\
\hline TOTAL & 618 & $100.0 \%$ \\
\hline
\end{tabular}




\section{GEOGRAPHIC DISTRIBUTION}

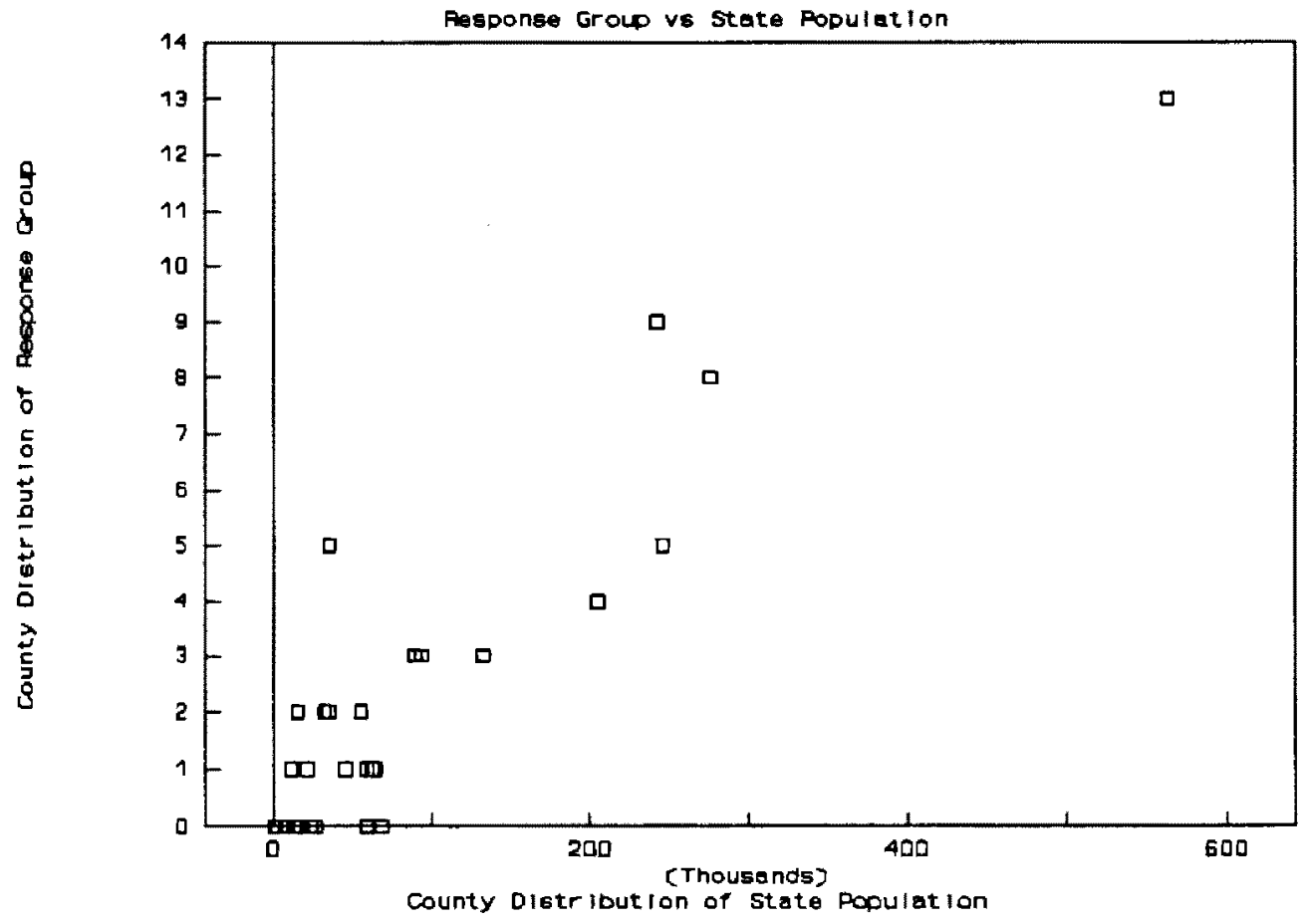

Figure 3. Comparison of Response Group and state Population Geographic Distribution. Source of state population by county: Center for population Research and census (1991). 
The close approximation of the response group and state population geographic distribution suggested that the responses may have been representative of the various economic and employment environments which workers would experience in various parts of the state. The high geographic correlation was important in achieving survey results which would more likely reflect the economic diversity of the state.

\section{Age and Gender of Response Group}

The proportion of males to females in the response group differed from that of the study group. Males accounted for $75 \%$ of the study group but $89 \%$ of the response group. Females comprised $25 \%$ of the study group but only $11 \%$ of the response group.

The only study group age data available for purposes of comparison to the response group was distribution data with age-at-injury grouped by age classifications expressed as a percentage of the whole group (Oregon Department of Insurance * Finance, 1988, p.11). Due to the lapse in time from age-at-injury to the end of the study, the end of the 4 th quarter of 1990 (Q4'90), a projected current age ${ }^{1}$ was used as a comparison base between the response group and the study group. In 1986, approximately $75 \%$ of the study group

1 The study group median year-at-injury was calculated from the Dates of Injury distribution chart (Department of Insurance \& Finance, 1988, p.31) to be 1982. Eight years was then added to all the age classifications to shift the age-atinjury profile, in order to make a rough approximation of current age distribution of the study group. 
age-at-injury was between the ages of 25 and 44 . An eight year age shift to project current ages resulted in a projected age distribution in which $70 \%$ of the population between the ages of 33 and 52. In the response group, age was more evenly distributed with approximately 778 of the population falling between the ages of 38 and 62 (Figure 4). A paired-sample t-test was calculated to assess the probability that the response group's current ages were representative of the study group's projected current ages. Results (Table VI) indicated that the means for the two groups were not significantly different. It could therefore be assumed that the response group approximated of the study group with respect to age.

HYPOTHESIS

Based upon the results of the 1988 study of this group (Oregon Department of Insurance and Finance, 1988), it was hypothesized that the Authorized Training Programs would provide long-term benefit to program recipients. Three criteria were used to measure the effectiveness of the program: (1) earning capacity; (2) employment status; and (3) training goal viability. 


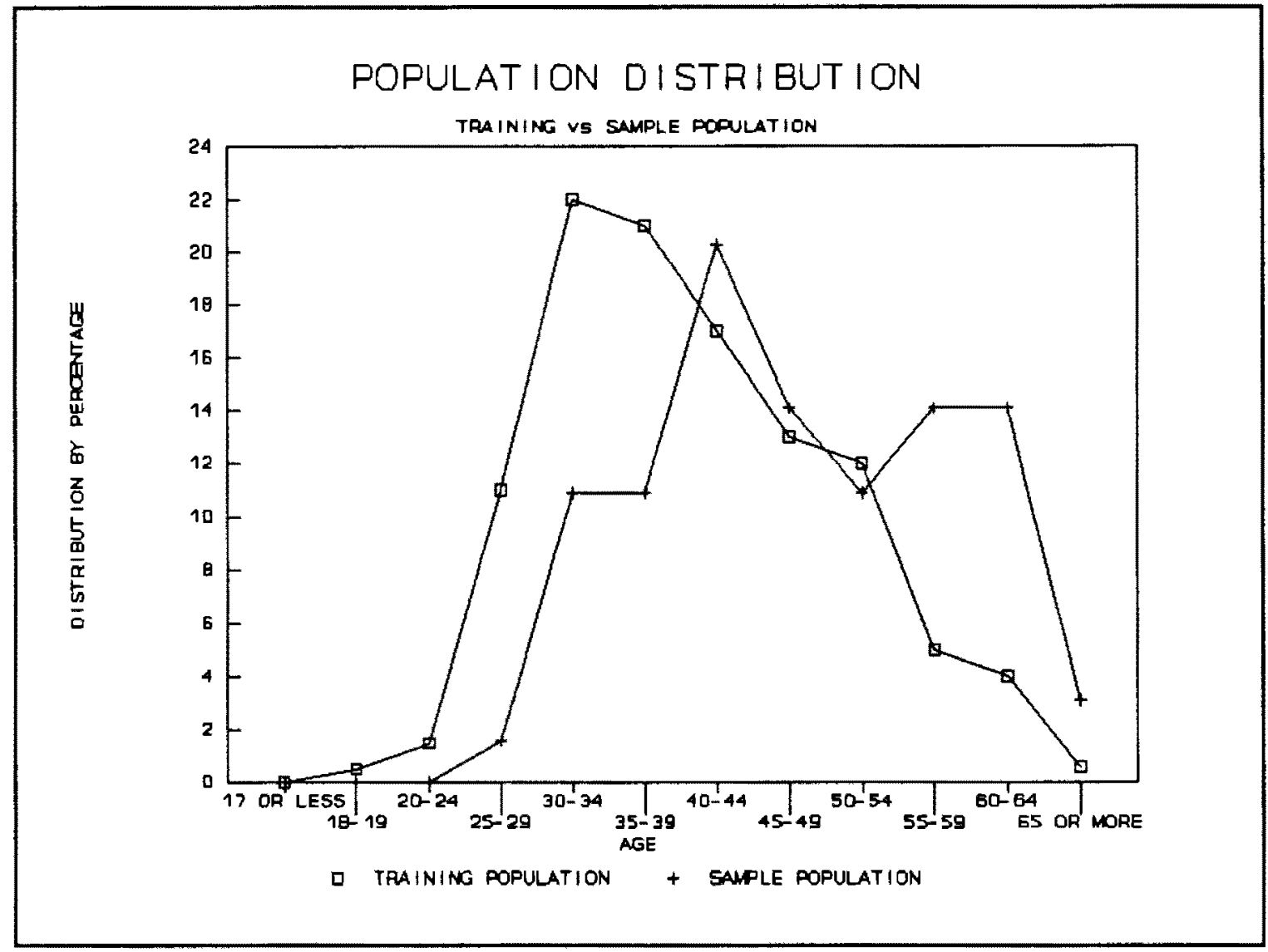

Figure 4. Comparison of Response Group Age Distribution and Sample Group Projected Age Distribution. 
TABLE VI

t-TEST RESULTS OF RESPONSE GROUP AND STUDY GROUP FOR AGE DISTRIBUTION

\begin{tabular}{|l|c|c|c|c|c|c|}
\hline \multicolumn{1}{|c|}{ Current Age } & N & Mean & SD & $t$ & DF & Prob \\
\hline Study Group & 1229 & n.a. & n.a. & & & \\
Response Group & 73 & 47.7 & 10.2 & .01 & 11 & .992 \\
\hline
\end{tabular}




\section{CHAPTER IV}

\section{FINDINGS}

The effectiveness of Authorized Training Programs (ATPS) was assessed in terms of the following factors: current wages with respect to wage-at-injury, (2) current employment status and length of time in competitive employment, and (3) the relationship between the job classification of the training goal and the current job classification. Each factor was assessed separately.

\section{WAGE-AT-INJURY AND CURRENT WAGES}

To evaluate the effectiveness of ATPs with respect to wage, a comparison was made between the wage-at-injury and the current or last wage of the response group. For purposes of comparison, all wages were expressed as hourly wages.

The current wage was the reported wage earned at the end of Q4'90. The last wage was the wage reported prior to withdrawal from the labor market. To more accurately compare current/last wage (wages earned in 1990) to wage-at- 
injury, the current wage was adjusted downwards by an inflation factor of $.3175^{1}$. The wage-at-injury is the wage reported by the respondents as the wage accepted by the Oregon Workers' Compensation Department as the compensable wage at the time of the industrial accident. For purposes of evaluation, the average state wage for 1982, the median year-of-injury of the study group, was used as the basis for wage comparison.

The distribution patterns of wage-at-injury and of the current adjusted wage were reviewed (See Appendix C, p. 42, for histograms). The pre-injury wage distribution pattern was characterized by a more compact pattern. Wages ranged from $\$ 3.35 / \mathrm{hr}$ to $\$ 48 / \mathrm{hr}$ with most individuals earning wages clustered about the mean of $\$ 11.35 / \mathrm{hr}$. In contrast, the post-injury adjusted wage was skewed to the left and wages were more dispersed over a more narrow range -- from $\$ 0.00$ to $\$ 17.06 / \mathrm{hr}$. Mean adjusted response group wage was $\$ 4.54 / \mathrm{hr}$. Mean adjusted last/current wage for those who were employed was $\$ 6.76 / \mathrm{hr}$.

1 The inflation adjustment is based upon state average wage information requested from the oregon Employment Division, statistics and Research Section, in a telephone conversation on July 11, 1991. The average state wage covered by unemployment insurance (UPI) for 1982 was $\$ 7.78 / \mathrm{hr}$. The unofficial and, as yet, unpublished 1990 average state UPI wage for 1990 was $\$ 10.25 / \mathrm{hr}$. The wage difference represents a $\$ 2.47 / \mathrm{hr}$ increase in wages over the eight year period -which is the 31.75\% adjustment factor (Employment Division, 1991). 
As the comparison groups were randomly formed, an independent (two-sample) t-test was used to determine whether the means of the wage-at-injury and the current/last wage were different at $\alpha=.05\left(\mathrm{H}_{0}\right.$ : the mean of the last/current wage equals the mean of the wage-at-injury). Paired-sample t-tests were run utilizing both the adjusted last/current wage and the reported last/current wage.

As the results in Table VII show, both $t$ values were sufficiently high to allow for the rejection of the null hypothesis at a p-value of $<.001$ between the adjusted wage and the wage-at-injury and a p-value of $<.001$ between the last/current wage and wage-at-injury. Based upon a statistically discernable difference in the mean wage analysis, it appears that ATPs are not very effective in helping injured workers return to pre-injury-wage-earning capacity.

\section{COMPETITIVE EMPLOYMENT STATUS}

Competitive employment status was evaluated based upon the rate of current unemployment among the response group, a comparison of the response group unemployment rate to the current state unemployment rate, and an analysis of the percent of weeks worked from Q1'85 to Q4'90. Response group profiles based upon employment status were developed (Table VIII). The response group unemployment rate was 56.2\%. Among the respondents, 23 (31.5\%) never returned to competi- 
TABLE VII

MEANS, STANDARD DEVIATIONS, AND I-TEST RESULTS FOR ADJUSTED WAGE, LAST/CURRENT WAGE AND WAGE-AT-INJURY

\begin{tabular}{||c|c|c|c|c|c|c|}
\hline Wage Type & $\mathrm{N}$ & Mean & SD & $t$ & DF & Prob \\
\hline $\begin{array}{l}\text { Adjusted } \\
\text { Wage (present) }\end{array}$ & 73 & 4.54 & 4.304 & & & \\
$\begin{array}{l}\text { Wage-at- } \\
\text { Injury }\end{array}$ & 68 & 11.353 & 6.186 & 7.189 & 67 & $<.001$ \\
$\begin{array}{l}\text { Last/Current } \\
\text { Wage }\end{array}$ & 73 & 6.652 & 6.306 & 4.157 & 67 & $<.001$ \\
\hline
\end{tabular}

1 The differences in the sample size $\mathrm{N}$ occurred as the result of missing data on various questionnaires. Unreported data was entered as "no value." For purposes of statistical calculation those records were ignored if missing data significant to the calculation was encountered.

\section{TABLE VIII}

PROFILE OF RESPONDENTS BASED UPON EMPLOYMENT STATUS

\begin{tabular}{||l|l|l|}
\hline CATEGORIES & EMPLOYED & UNEMPLOYED \\
\hline No. of Respondents & 32 & 41 \\
Average Age & 44.8 & 50.1 \\
Avg Wage-at-Ipjury & 11.50 & 11.05 \\
Avg Last Wage & 10.02 & 9.13 \\
Wage/Wage-at-Injury & 88.78 & 82.68 \\
Avg Weeks Worked & 220 & 37 \\
o-Weeks Worked & 76.48 & 12.98 \\
Count: Never Worked & 0 & 23 \\
\hline
\end{tabular}

1 Mean last wage includes only unadjusted wages of those workers who entered the competitive labor market for any amount of time following training. $\$ 0.00$ wages of individuals never returning to competitive employment were excluded from the calculation. 
tive employment, one worker committed suicide and one workrelated death was reported. The state unemployment rate in 1990 was $5.5 \%$ (Anderson, 1991).

Among the $56.2 \%$ currently unemployed, the average number of weeks worked during the study period was 37 representing a 12.98 weeks worked rate. By contrast, the productivity rate, as measured by weeks worked, of the $43.8 \%$ currently employed was $73.1 \%$ weeks worked.

\section{TRAINING GOAL VIABILITY}

Training goal viability was evaluated by tabulating the number of respondents who reported working in the field for which they were trained. The categorization of respondents by "same" or "different" (Appendix D) reflects the relationship between their last competitive employment and the training goal (Tables $I X$ and $X$ ). Among the respondents, 52.18 reported last or current employment related to training. The remaining $45.2 \%$ responding to the question (two respondents (2.7\%) did not provide appropriate information), reported as either never achieving competitive employment or as being employed in a field unrelated to their training. Although the most productive group is currently employed in the field in which they were trained, $71.2 \%$ of the respondents are either unemployed or employed in a field different from the field in which they were trained. 
TABLE IX

PROFILE OF RESPONDENTS BASED ON GOAL VIABILITY

\begin{tabular}{||l|l|l|l|l||}
\hline \hline CATEGORY & $\begin{array}{l}\text { DIFFERENT } \\
\text { UNEMPLOYED }\end{array}$ & $\begin{array}{l}\text { DIFFERENT } \\
\text { EMPLOYED }\end{array}$ & $\begin{array}{l}\text { SAME } \\
\text { UNEMPLOYED }\end{array}$ & $\begin{array}{l}\text { SAME } \\
\text { EMPLOYED }\end{array}$ \\
\hline No. Workers & 22 & 11 & 17 & \\
Average Age & 52 & 43.5 & 48 & 21 \\
Avg Wage-at-Ipjury & 12.25 & 9.72 & 9.1 & 45 \\
Avg Last Wage & 12.41 & 8.47 & 8.16 & 12.43 \\
Wage/Wage-at-Injury & $101.3 \%$ & $87.1 \%$ & $89.7 \%$ & 10.84 \\
Avg Weeks Worked & 10 & 181 & 61 & $27.2 \%$ \\
\% Weeks Worked & $3.5 \%$ & $62.8 \%$ & $21.2 \%$ & $83.3 \%$ \\
Count: Never Worked & 19 & 0 & 3 & 0 \\
\hline
\end{tabular}

1 Mean last wage includes only unadjusted wages of those workers who entered the competitive labor market for any amount of time following training. $\$ 0.00$ wages of individuals never returning to competitive employment were excluded from the calculation.

\section{TABLE $X$}

SUMMARY PROFILES BASED ON GOAL VIABILITY

\begin{tabular}{||l|l|l||}
\hline CATEGORIES & DIFFERENT & SAME \\
\hline No. of Respondents & 33 & 38 \\
Average Age & 49.0 & 46.7 \\
Avg Wage-at-Ipjury & 11.32 & 10.99 \\
Avg Last Wage & 9.07 & 9.81 \\
Wage/Wage-at-Injury & $80.1 \%$ & $89.3 \%$ \\
Avg Weeks Worked & 67 & 160 \\
\%-Weeks Worked & $23.3 \%$ & $55.5 \%$ \\
Count: Never Worked & 19 & 3 \\
\hline
\end{tabular}

1 Mean last wage includes only unadjusted wages of those workers who entered the competitive labor market for any amount of time following training. $\$ 0.00$ wages of individuals never returning to competitive employment were excluded from the calculation. 


\section{CHAPTER V \\ CONCLUSIONS AND RECOMMENDATIONS}

\section{CONCLUSIONS}

On the basis of all three criteria of evaluation, it would appear that authorized training programs have been ineffective in meeting the needs of the injured workers responding to the survey. The majority of recipients of Authorized Training Programs failed to achieve their preinjury earning capacity, failed to maintain long-term gainful competitive employment and more than two-thirds of the respondents were either unemployed or employed in a field other than the field in which they had received training. Due to the low response rate, despite the favorable age and geographic distribution patterns, generalizing the results of the survey to the general population of injured workers should be done with caution.

\section{Worker Profile}

The most productive group of workers in terms of posttraining weeks worked are the workers who are currently employed in occupations in the field of their training (Table XI). The two most notable factors about this group are the workers' fairly young average age (45) and the 
TABLE XI

PROFILE OF WORKERS EMPLOYED IN TRAINING FIELD

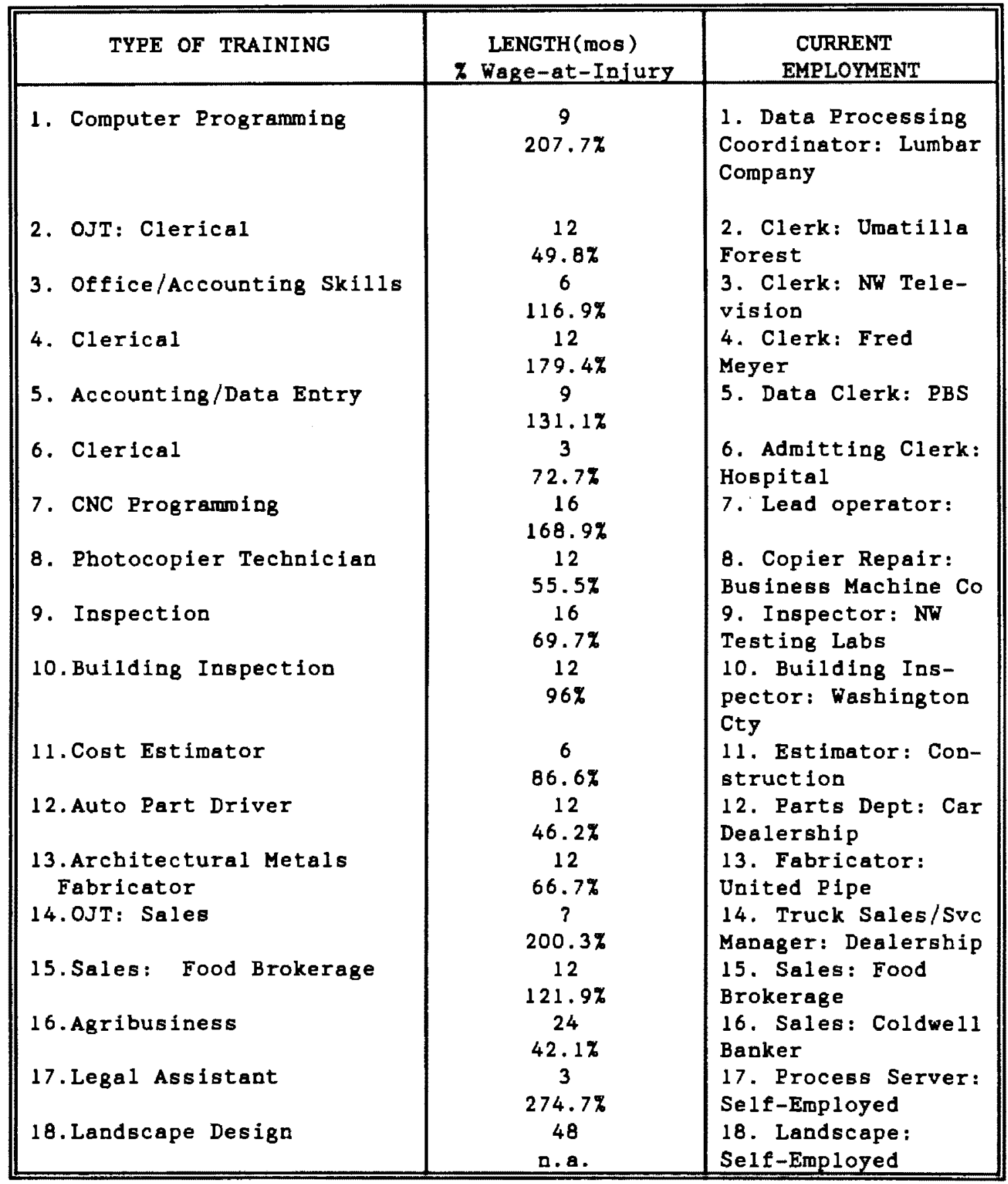


workers' high average wage-at-injury $(\$ 12.43 / \mathrm{hr})$. Consistent with Hester's (1990b) belief, the pre-injury motivation and occupation level of the workers appears to be reflected in higher levels of post-training employment achievement. The group's average training period is approximately twelve months. The shortest training period was three months and the longest training period was four years. The average productivity rate (percentage of total weeks worked from Q1'85 through Q4'90) was $83 \%$.

within this group of 21 workers, however, only 10 (47\%) are currently receiving wages at $80 \%$ or more of their wageat-injury. All of the clerical workers currently receiving wages greater than their wage-at-injury are females. Among the workers in this group the three females had the lowest wages-at-injury $(\$ 7.40, \$ 3.35$ and $\$ 5.60 / \mathrm{hr})$. Their posttraining wages are below the current average wage in the Portland Metropolitan area (approximately $\$ 10.00 / \mathrm{hr}$ ). Other workers, who are currently receiving wages $80 \%$ or more of wage-at-injury, trained and are engaged in the following occupations: salesman, self-employed process server, selfemployed landscape gardener, construction estimator, building inspector, computer programmer and high-tech machine operator.

The wages of the other 11 workers range from $42.1 \%$ to $72.7 \%$ of wage-at-injury; the average wage of these 11 workers is $55.5 \%$ of wage-at-injury. Even among this productive 
group, the majority of individuals have experienced substantial loss of earning capacity.

Factors inherent in the individuals involved in rehabilitation, and independent of the training itself may also have impacted long-term productivity. Hester (1990b) contends that age is negatively correlated to rehabilitation potential. This contention appears consistent with report findings. The group with the lowest productivity rate (3.5\%) and highest number of workers never returning to competitive employment (19) also has the highest average age (52 years). The age differential between the unemployed and employed groups is about five years. There is a seven year gap between the least and most productive group of workers.

\section{A Review of Worker Comments}

A review of the comments respondents included on their questionnaire forms (Appendix B) offers insight into the workers' point of view. The following is a paraphrased compilation of the most common problems the workers' experienced during the rehabilitation process and after re-entering the competitive labor market:

1. The training goal was poor. There were no viable employment options once training was complete. The worker was unable to tolerate work conditions (e.g., fumes).

2. The training was too short and/or too fast. The worker felt ill-prepared for the field at the completion of 
training. The worker was unable to complete training due to rehabilitation restrictions.

3. The worker disliked the training goal.

4. There was inadequate earning potential in the field of training.

5. Workers were unable to find long-term employment. Employers discriminated against injured workers. Workers were placed with employers who were financially unstable and eventually went out of business.

The problems with vocational rehabilitation organizations (VROs) experienced by the response group are similar to problems found in other studies discussed in chapter II (Congress of the U.S., Hearings, 1988; Murphy, 1988;

Wilgosh, 1988). Based upon comments from response group members, it would appear that injury-related issues traditionally perceived as unrelated to vocational issues also impact return-to-work rates and productivity. It would seem appropriate to take a more holistic approach and to address all issues related to the abrupt changes in lifestyle experienced by the permanently disabled worker. Long term prospects for rehabilitation and increased productivity may be improved if the workers are given the opportunity to work through resultant changes in their lifestyle and career necessitated by the injury-related disability. 
Occupational Trends

Among those reporting competitive employment following training there was a dramatic shift in occupation classification (See Appendix E for detailed information, and Figure 5, for trend.). Workers moved from generally higher paying occupations in the labor, operator, transport and craft classifications to traditionally less lucrative, but generally lighter duty occupations in the sales, managerial, service, and administrative and technical support classifications. This requirement for lighter duty occupations, when not accompanied by training which allows workers to enter the more lucrative technical or managerial fields, generally results in a dramatic loss of earning capacity.

Changes in the oregon labor market have also impacted the earning potential of response group members. The loss of jobs in timber-related industries have not been offset by gains in other equally lucrative blue collar jobs in other types of manufacturing. The contraction of the manufacturing sector and expansion of the service sector represents a real loss of earning potential for many oregonians. Middle income jobs are being lost and are replaced, in many areas, by jobs approaching minimum wage. This profound economic change is felt throughout the nation and can only be addressed on a state and national scale. 


\section{OCCUPATION SHIFT}

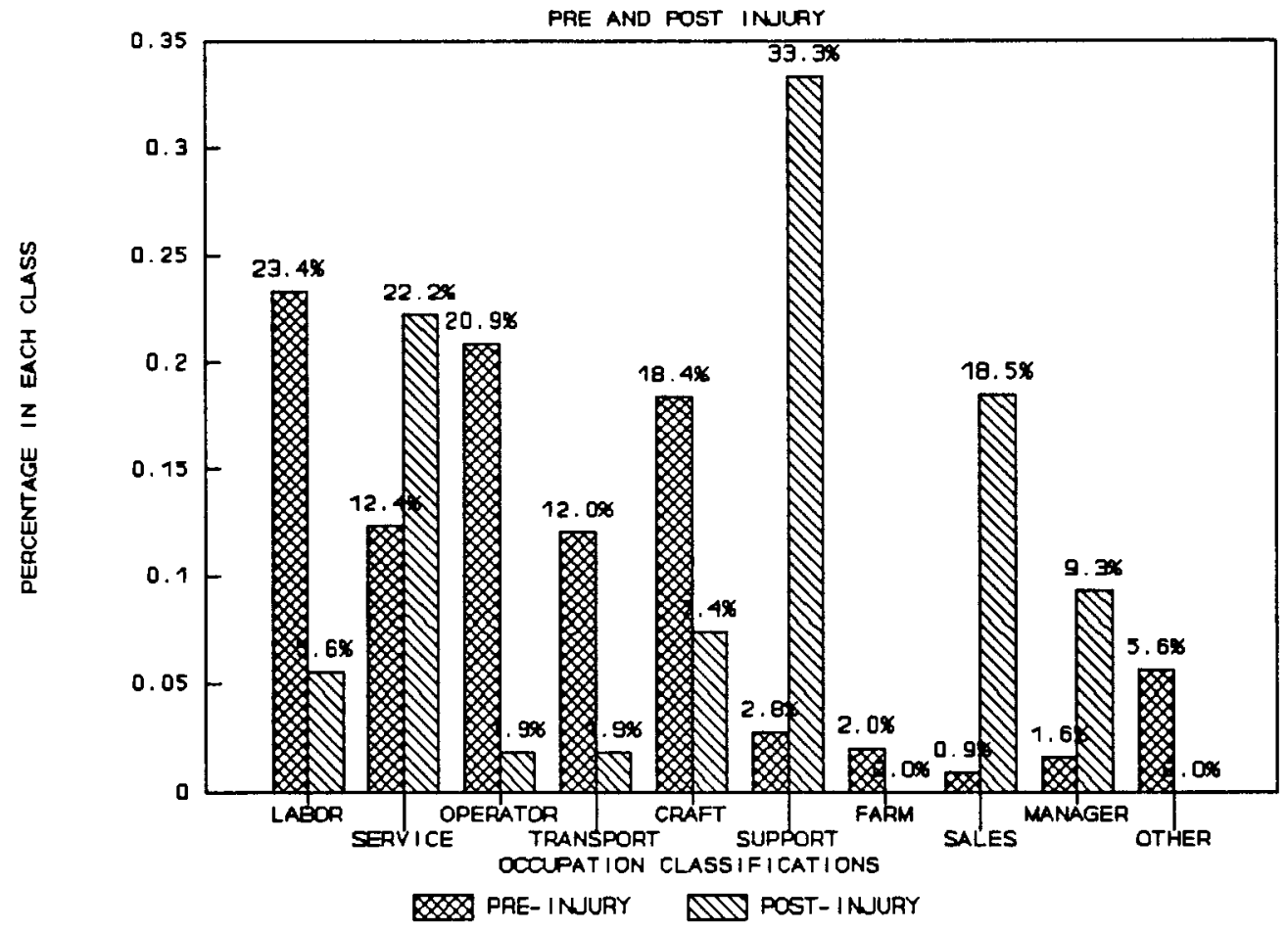

Fiqure 5. Shift in Occupational classification Pre- and Post-Injury. 


\section{Social Impact of Work Injury}

Some degree of life-style disruption would most likely be anticipated as a result of a permanent, partially disabling injury and was apparently experienced by many of the respondents. The mobility rate among the study group (36\%) appears to be significantly higher than that for the general population. Fourteen percent (14\%) attributed a change in marital status and number of dependents supported to the industrial injury. Approximately $22 \%$ report an injuryrelated change in status as sole wage earner. The current unemployment rate among the response group was $56.2 \%$. The Workers' Compensation system in Oregon appears to have fallen short of mitigating injury-incurred damages in terms of the cost to the worker in pain, in the loss of lifestyle and in loss of economic opportunity.

\section{Changes from 1988 to 1990}

According to the oregon Department of Insurance and Finance, at the end of rehabilitation training, the returnto-work rate of the study group was $61 \%$; the unemployment rate was $39 \%$ (p. 3). At the end of 1990 , the unemployment rate was found to be 56\%, an increase of $17 \%$. Reports of "real wages substantially increasing over time" (Oregon Department of Insurance and Finance, 1988, p. 3), are not reflected in the response group wages. Although mean unadjusted wage of workers currently employed is $87.1 \%$ of wageat-injury, adjusted mean wage is $60 \%$ of wage-at-injury. The 
Oregon Department of Insurance and Finance (p. 3), reported 70.78 of the 1986 training case workers returning to work in an occupation related to their training. Among the response group, $71.2 \%$ of the workers are either unemployed or employed in a field other than the field in which they were trained; 47.98 reported their last occupation as being in a field different from the field in which they were trained. Although initially the training programs appeared to offer promise (based upon the 1988 study), over time, the unemployment rate among the study group appears to have increased, real earning capacity appears to have been impaired among the group which has maintained employment, and there has been movement out of the fields in which these workers received training. Only a relatively small proportion of workers in the response group appears to have substantially benefitted from their training programs.

\section{RECOMMENDATIONS}

\section{Training Program Modifications}

Training program modifications which might prove beneficial in achieving a more successful transition to alternative employment would involve the inclusion of the following steps:

1. Mandatory vocational evaluation. This would include interest and temperament instruments as well as apti- 
tude and ability testing. Suitability for training, as well as for particular occupations, should be assessed.

2. On-site vocational assessment. Prior to selecting a training goal and investing training funds, the workers should be exposed to the job in a competitive work setting for an extended period of time. Suitability should be assessed in terms of aptitude and ability to perform the job, a correspondence to the worker's residual physical capabilities and, to assure long-term productivity, a correspondence to the worker's temperament and interest profile.

3. Mandatory proof of worker approval of the training goal. A contractual agreement, similar to those employed in the state and Federal Vocational Rehabilitation systems, could be used. VRD plans require client written endorsement of the plan prior to its initiation.

4. Adequate labor market analysis which includes projected future employment of the training goal in the geographic area in which the worker would be employed.

5. Training programs which prepare workers for occupations which offer earning potential comparable to pre-injury earning capacity.

6. Inclusion of counseling services which would ease the transition to an alternative vocation and lifestyle. Although many of these elements have been used sporadically in the past, the comments of the response group indicate the incorporation of all elements on a consistent basis 
is not being accomplished. The cost of inclusion of these elements in the formulation of a training plan may be offset by the increased productivity of workers more suitably placed.

\section{Future Research}

At the present, changes of regulations allow injured workers to compromise and release their claims against employers for a cash settlement. Generally, as part of the settlement, the worker relinquishes rights to vocational rehabilitation services. Studies comparing the post-release competitive work history of workers who compromised and released their claims to workers who received vocational rehabilitation services would be of value. of special interest would be a comparison of aggravation and re-injury rates, as well as, productivity rates between the two groups.

At present, there appears to be an increasing number of injured workers applying for services at the Vocational Rehabilitation Division (VRD). It is surmised that many of the injured workers currently applying to VRD are workers who have either compromised and released their claims and collected a cash settlement in lieu of services, or are injured workers whose wages-at-injury were close to entrylevel wages and were, consequently, not offered vocational services. A study determining the type of injured-workers seeking services outside the Workers' Compensation system 
and a study compiling the cost in public funds (welfare funds or VRD funds) required to service injured workers would be helpful in assessing the overall, long-term cost of work-related injuries.

Proposals by the California senate committee (Thompson, 1990) and from a litany of studies exploring a more longterm, holistic approach to rehabilitation (Bordieri, 1986; Botterbusch, 1989; Roessler \& Bolton, 1985) call for a restructuring of the Workers' Compensation system. Confining rehabilitation to a single-shot settlement or a singletime rehabilitation effort apparently does not appear to have met the needs of injured workers who experience the residual effects of their disabling injury for a life time. A more realistic approach which acknowledges the need for continuing supportive services to maximize worker potential would also more realistically reflect the long-term cost of such programs. By combining services with other rehabilitation programs already in place and by supporting the move toward controlling runaway medical costs with scheduled rates or the required use of health maintenance organizations, overall program cost can, perhaps, be reduced and services to the injured worker can be improved.

\section{The Field of Private Vocational Rehabilitation}

Current legislation has further eroded the potential for adequate vocational training and services. As a result, it is clear that rehabilitation of the injured worker is 
currently making little headway in remediation of the devastation caused by disabling industrial injury.

If rehabilitation counselors desire to remain a viable component within the Workers' Compensation environment in Oregon, they must prove the services they perform are both effective and have a positive cost-benefit ratio. The development of successful training and job placement programs is critical. Although the response rate of the survey was far too small to generalize results to the general population of injured workers, the comments of the respondents should be taken seriously. Based upon survey results, more effort appears to be required to establish rapport with clients, to critically assess client needs, abilities and interests, and to develop a program which adequately reflects the market place. As Berkowitz and Berkowitz (1991) warned, the rehabilitation community must respond to the current challenges to the profession or lose the field entirely to others less suited to meet the needs of this interesting population:

The time is ripe for vocational rehabilitation to meet the challenges by marshalling the evidence. If the profession does not join in mounting the necessary inquires, they will be conducted by others who may not appreciate the potential of the work that is being done by rehabilitation and the field will go by default. The time to move is now before rehabilitation in workers compensation is further eroded or the field is left to claims adjusters who usurp the name of the profession. (p. 196) 


\section{REFERENCES}

Akabas, S.H. (1990). The work ethic is alive and well: Its impact on persons with disabilities. In $S$. J. Scheer (Ed.), Multidisciplinary perspectives in vocational assessment of impaired workers (pp. xvii-xxiii). Rockville, MD: Aspen.

Anderson, J. (1991). Business \& employment outlook, JTPADistrict 7. State of Oregon, Employment Division, Department of Human Resources.

Beauchamp, M. (1990, October). Spitting out the bone. Forbes, pp. 260-261.

Berkowitz, M. \& Berkowitz, E.D. (1991). Rehabilitation in the work injury program. Rehabilitation Counseling Bulletin, 34, 182-196.

Bordieri, J.E. (1986). Employment alternatives for workers with disabilities: An international perspective. Washington, D.C.: National Institute of Handicapped Research. (ERIC Document Reproduction Service No. ED 267 228.

Boschen, K.A. (1989). Early intervention in vocational rehabilitation. Rehabilitation Counseling Bulletin, 32, $254-65$.

Botterbusch, K.F. (1989). Understanding community based employment and follow-up services. Washington, D.C.: National Institute on Disability and Rehabilitation Research. (ERIC Document Reproduction Service No. ED 309 274)

California Workers' Compensation Institute (WCI). (1983). A report to the industry: Vocational rehabilitation. San Francisco, CA.

Center for Population Research and Census (1991). Components of population change by county: April 1, 1980 July 1, 1990. Portland, OR: School of Urban and Public Affairs, Portland state University. 
Congress of the United States, House Committee on Veterans' Affairs. (11 May 1988). The vocational rehabilitation program. Hearings before the Subcommittee on Education, Training and Employment of the committee on Veterans' Affairs, House of Representatives, one Hundredth Congress, First Session. (Serial No. 100-47) Washington, D.C.: U.S. Government Printing office.

Demore-Tabore, M. \& Cohen-Siskind, B.M. (1990). The role of the vocational rehabilitation counselor. In $S$. J. Scheer (Ed.), Multidisciplinary perspectives in vocational assessment of impaired workers (pp. 47-60). Rockville, MD: Aspen.

Deneen, L.J., \& Hessellund, T.A. (1981). Vocational rehabilitation of the injured worker. San Francisco: Rehab Publications.

Downton, J., Felt, L. \& House, D. (1987). Evaluation of the rehabilitation programs of the workers' compensation commission of Newfoundland and Labrador. Memorial University of Newfoundland: The Institute of Social and Economic Research (ISER).

Employment Division (1991, July 11). State average wage: 1982 and 1990 [telephone conversation]. Portland, OR: state of Oregon, Department of Human Resources.

Fierro, R.J. \& Leal, A. (1988). Psychological effects of early versus late referral to the vocational rehabilitation process: The case of Mexican origin industrially injured workers. Journal of Applied Rehabilitation Counseling, $19,35-39$.

Francis, D. (1989, July 10). Costly help for the wounded. Maclean's, p. 11 .

Friedman, G. (1986). The anatomy of work. New York: The Free Press of Glencoe, Inc.

Goodwin, L. (1972). Do the poor want to work? Washington D.C.: The Brookings Institution.

Hester E.J. (1990a). Workers who become disabled. In $\mathbf{S}$. J. Scheer (Ed.), Multidisciplinary perspectives in vocational assessment of impaired workers (pp. 1-17). Rockville, MD: Aspen.

Hester, E.J. (1990b). Disability and disincentives: Prospective models for change. In S. J. Scheer (Ed.), Multidisciplinary perspectives in vocational assessment of impaired workers (pp. 205-218). Rockville, MD: Aspen. 
Jackson, Z.P. (1984). Alaska revisited. Juneau, Alaska: Alaska Workers' Compensation Division.

Keisling, P. (1991-92). oregon blue book. Salem: oregon state Printing Division.

Maine Workers' Compensation Commission. (1988). Vocational rehabilitation under the Maine workers' compensation act 39 M.R.S.A. 81-90. Portland, Maine.

Manley, M., (1991). Employment, disabling claims, and claims rates: Oregon 1980-1990. Preliminary unpublished figures calculated by Research \& Analysis Section, oregon Department of Insurance and Finance.

Murphy, S.T. (1988). Counselor and client views of vocational rehabilitation success and failure: A qualitative study. Rehabilitation Counseling Bulletin, 31, 185-97.

Olsheski, J. \& Growick, B. (1988). Industrial rehabilitation in the public sector: The ohio experience. Paper presented at the Annual Convention of the American Association for Counseling and Development, Chicago, IL. (ERIC Document Reproduction Service No. ED 294 110)

Oregon Department of Insurance and Finance (1988). Report to the oregon legislature on workers' compensation vocational rehabilitation training cases completed in 1985 and 1986. Salem, OR: Research and Statistics section.

Oregon Department of Insurance and Finance (1990). Workers' compensation claims characteristics: Calendar year 1989 [pamphlet]. Salem, OR: Research and Statistics Section.

Oregon Department of Insurance and Finance (N.D.). Names and addresses of the study group for the report to the oregon legislature on workers' compensation vocational rehabilitation training cases completed in 1985 and 1986 [Machine-readable data file]. Salem, OR: Research and statistics section.

Roessler, R. \& Bolton, B. (1985). Employment patterns of former vocational rehabilitation clients and implications for rehabilitation practice. Rehabilitation counseling Bulletin, 28, 178-87.

Shrey, D.E. (1990). Disability management: An employerbased rehabilitation concept. In S. J. Scheer (Ed.), Multidisciplinary perspectives in vocational assessment of impaired workers (pp. 89-103). Rockville, MD: Aspen. 
Tinsley, L.C. (1988, January). State workers' compensation: legislation enacted in 1987. Monthly Labor Review, pp. $62-68$ ).

Thompson, R. (1990, March). Fighting the high cost of workers' comp. Nation's Business, pp. 20-26.

Vocational Assistance to Injured Workers, Oregon Administrative Rules (OAR) \$\$ Chapter 436-120 (1988).

Wilgosh, I. (1988). The world of work: Is there a match between vocational preparation and employer expectations? In D. Baine (Ed.), Alternative futures for the education of students with severe disabilities (pp.764782). Alberta, Canada.

Worker's Compensation, Administration, Oregon Revised statutes. \$\$ ORS 656.726(3) (1985).

Wright, B.A. (1983). Physical disability: A psychosocial approach. New York: Harper \& Row, Publishers. 
APPENDIX A

SURVEY INSTRUMENT AND COVER LETTER 


\section{Portland State University}

P.O. Bax 751. Pordand. OR 97307-0751

octobex 11, 1990

The Rehabilitation Counseling Program at Portland state Universi$t y$ is conducting an independent follow-up study of all of the workers who completed vocational training during 1985 or 1986 , as part of the rehabilitation programs of the Workers' compensation Division of the state of Oregon.

Our records show that you are one of the workers who completed training during this period. Please take a few minutes to complete the enclosed questionnaire describing your work history since your participation in vocational rehabilitation. When you have completed the survey, please return it in the stamped, selfaddressed envelope provided. In order to protect your privacy. please do not wite your name, address or claim number anywere on the questionnaire or the return envelope. Information gathered in this report will be reported as summary information only.

Your cooperation in this study is entirely voluntary, but it is essential to the success of the study. Your participation will provide valuable information which will help in improving the quality of vocational rehabllitation in the state of oregon.

Please tyy to return this form by March 15,1991 . We appreciate your participation. If you have any questions about the study, please feel free to contact Grace Han at 646-8200.

Thank you very much,

Dr. Hanoch LIvneh

Rehabilitation Counseling Coordinator 
1990 Vocat Ional Rehabliltation TralnIng study Quest Ionnalre

PART I: Enploymont HIstory

1. What was your wago-at-Injury?

8. 5

b. Was thle per hour

per weok

per no _-?

2. What tralning did you recelve through Workers' Compensation?

a. Titie/typo

b. Length of training Yro Days

3. Have you been employed at any time since completing training?

YES

No

4. If you answered "yes" to question 2, please Ilst the following Information about EACH JOb since your particlpation in the vocational rehabliltation program:

a. Employer:

b. Job:

c. Do you foel the training you recelved helped you perform thls Job: YES _ NO__ OTHER

d. Which quarters (AFTER partlclpation) wore you omployed, how many weoks did you work in each quarter, and how much did you oarn (before taxes)?

cuarter worked

Jan - Mar 1985

Apr - Jun 1985

Jul - Sep 1985

Oct - Dec 1985

Jan - Mar 1986

Apr - Jun 1986

JuI - Sep 1986

Oct - Dec 1986

Jan - Mar 1987

Apr - Jun 1987

Jul - Sep 1987

Oct - Dec 1987

Jan - Mar 1988

Apr - Jun 1988

JuI - Sep 1988

Oct - Dec 1988

Jan - Mar 1989

Apr - Jun 1989

Jul - Sep 1989

Oct - Dec 1989

Jan - Mar 1990

Apr - Jun 1990

JuI - Sep 1990

Oct - Dec 1990 moeks Worked (12 por quartor)

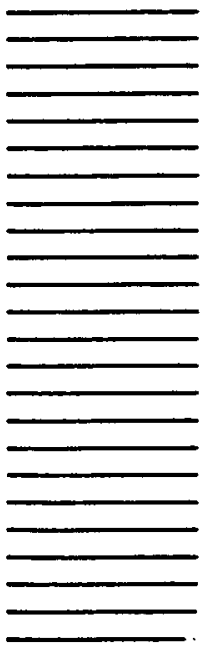

Hour Iy Wage

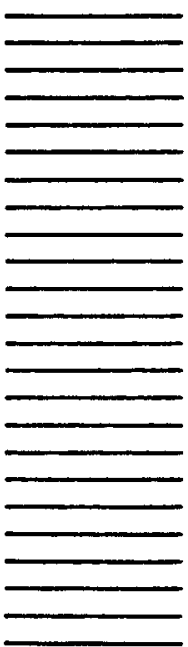

If you have he more than one Job since completing training, please attach additional sheets of paper. Your response is Important for evaluating the vocational ronabliltation program. Thank you! 
PART 1I: Personal Information

1. What is your age?

2. What is your sex?

3. In what county do you live?

4. How long have you been in the work force? year 8

5. What is your marltal atatus? singlo___ Marrled_____ Divorced/Separated

single Parent other

6. How many dependents are you supporting?

7. Are you the sole wage earner In the famliy?

YES

no

8. Check the HIGHEST level of educetion you have achleved:

Grade 8 or less

Grade 8 - 12

High School Graduato

Tech/Community col logo

UnIversity/collego

Degreo

other (please apec/fy)

Degree

0. Whleh of your clrcumstances described in quest lons 3 to 8 above have changed ince your injury? Plosso chock approprlate apace(s).
3 $\mathbf{5}$ 8. 7. 8

10. Did any of the changes descrlbed in 9 above occur as a result of your Injury?
YES
no
If yos, which ones?
3
5 6 B
Commente (if deslred): 
APPENDIX B

COMPILATION OF RESPONDENT COMMENTS 
COMMENTS RECEIVED FROM RESPONDENTS

1. I don't feel my re-training has helped me a bit to get a job - the training was not extensive enough and there is certainly no placement afterward - the whole thing was a waste of money. All work I have had since has been because of people $I$ know and I can't tell anyone about my knee injury or I won't be hired - thus the whole SAIF system is a total rip-off as far as I am concerned!

2. Waste of time \& money. No openings in the field. Pushed to take what was available. Training for free labor plus paid to train. No job at treatment plant. waste water jobs fill with clackamas college students.

3. The training I received at Chemeketa Community college was very good. From there I got a good job and I am still productively employed.

4. Could not be employed due to lack of training time by counselor and worker's compensation. My work history since injury has been sporadic and low paying since my infury. The work I have done has not been in any way connected to my training. Training by private rehab is the worst treatment an injured worker could have. Everybody profits from it except the injured worker yourself for instance!!!

5. After going to work for Pitney Bowes for 6 years, on March 30th 1990, I hurt my back on the job again. This time I have a bulging disk. Travelers Ins which carries comp. denied my claim \& then my employer fired me, because of the denials. That is where I am now.

6. Not able to work yet. I had back surgery last year and my doctor hasn't released me to work. Only training I completed was getting my GED.

7. My wife divorced me because I only made a small wage after my injury (as she said). She works full time \& I work part time. $\$ 5$ Bucks an hour ain't much after earning $\$ 15.50 / \mathrm{hr}$. I hope this survey helps some one because SAIF did not help me.

8. Fred Meyers Bakery $\$ 4.25$ Per hr during Jun 88 - Apr 89 no, job training did not help for this job

9. Cannot find a job now. It's not fair having to take such a wage cut. Not enough schooling to get a decent job. 
10. Jan-Apr 88: H\&R Block Inc, tax preparer; yes

Jul-Sep 88: T-V Hics CPA, Junior Accountant; yes

Oct-Dec 88: Harry \& David's, customer service; no

Jan-Mar 89: Junior accountant; yes

Apr-Sep 89: Kosmatka Donnally \& Co CPA's, jr accountant; yes

Oct-Dec 89: Harry \& David's, customer service; no cost accountant; yes

11. My life hasn't gotten any easier since my rehabilitation. In order to try to earn as much as $I$ was $I$ went on and got my BA degree. Because of an infection I got in the hospital I had a great deal of trouble getting through college. And because of both of the above, my family support system failed and I was divorced. And because of that I find myself chronically unemployed and unable to meet my financial responsibilities. I hope you can improve the system. Good luck!

12. I was encouraged to take up printing but was not told that all establishments require a minimum of two years training on experience. I was placed in a shop that was run by a homosexual who was going bankrupt and disparate for any free labor he could get. I was literally dropped. Note: I went on my own initiative and am now a senior supervisor for a security company. No thanks to the rehab people!

13. I have had lots of low paying jobs. I went from $\$ 28,000$ per year to around $\$ 12 \mathrm{k}$ to $\$ 15 \mathrm{k}$ per year. So call me, Joe Johansen, 661-0507 and I can fill your ear. I thank you for what you did, but when the wage sub was gone, so was I!. Would you take a chance of hiring someone with a back problem, if you didn't have to! My life time membership with the doctor from SAIF stooped and now I get to pay as I go. Call me, Joe.

14. I went back to my original trade in 1988. Could not live on wages I was making at Lane community College. Training was inferior. Couldn't handle maintenance. Injury got worse. Doctor ordered no more work. Training occurred in 1984. Was ordered to quit work and did Feb., 1985. Haven't worked since.

15. What I received from the system in education is in exact proportion to what $I$ put into it. What I learned may not have been transferable to the job I got, but it helped my self-esteem, got me back into the routine of work, and got my foot in the door to business. The career I have now is 180 degrees from my life as a manual laborer. I received 30 days training in floral 
design. But I fought and won for more training. I am now enrolled at LLC working on an associate degree as a professional secretary. I have 5 more terms left and feel that with this training $I$ will be able to make a decent wage of more than minimum wage.

16. I am sorry to return this late. My husband took his Iife October 18, 1988. He worked one year.

17. If I hadn't been injured, I would still be working. This computer training did me absolutely no good. The course was too fast and too short. Employers want a degree and more knowledge for this type of work. I ended up going back to what I was doing before I was injured. The money I would have made in computers with the knowledge I had when finished would have been, just above minimum wage.

18. The program helped me out. Self confidence and better writing skills. Thank you.

19. Lived briefly in Multnomah county (2-1/2 years). Then moved back to Lane county. The training program offered by Lane Community college was excellent. It is my understanding that I was the first workmen's comp participant to go through it. The dramatic change in my wages was due to the fact I chose to move back to my home town and knew I would have to take a cut in pay. The position at van Duyn proved to be very stressful.

20. Caused me to have many hardships. Because of doctor wrong reports and insurance company consultants harassment oregon workmen's compensation is a hoax.

21. The state of Oregon is the worst offender of discrimination of the handicapped. For example, the Justice Department is supposed to have a handicapped work force of 4\%. They are currently at 1.98 .

22. Surgery in 1985 weakened right arm and shoulder and right hand, especially fingers. I cannot keep typing speed which is required by employers. Medical field will not hire me because of right arm weakness. Danger when handling patients. Very disappointing because the knowledge I have and unable to use. I am now back where I started - compensating with left side.

23. I work each year from Mar 15 to Nov 4 as a waitress. Business closed for winter. After completing school, of which I paid for the last 2 semesters, I could have 
gone to work (if work was available) for less than half of what I was earning.

24. I feel that the rehab training should be given to people in some degree in the line of work that they think they would like. Not what the rehab counselor wants to make them take -- like was done with me. I hated electrical cost estimating so quit that went back to school and learned a trade that I like. That seems to mean or say that either rehab wasted their money or I did.

25. The state cut off all services after 12 months. I was only 1 semester away from completing the AA degree program that the state had already consented to. During the 12 months of schooling I doubled up on all my classes. I was taking twice the credits as a normal full time student and was still carrying an accumulated GPA of 4.0. I did more than my part and the state cut me off, no questions asked.

26. I became very ill due to panic syndrome with additional neurosis and depression. I worked for 3 months and was found wandering around the mill disoriented and frightened, and was told the next day not to return to work until I became well. My illness came on during the latter part of my re-training. I became ill upon walking into a class and became so ill that I could no longer drive to school, or even leave my home. In the interval between the onset of my symptoms and the preset there is very little change. . If any! The training was excellent but I just got sick.

27. My husband was unable to obtain adequate employment after rehabilitation. He returned to logging. He died in a logging accident in July, 1990.

28. \#3 - I had to sell my home and move. \#8 - I had to take the training they set up for me. I was already attending college at the time of my injury. VA benefit.

29. Retired on October 14, 1990. Not currently employed. I am glad I stood up for my rights.

30. Laid off -- family business did not have enough money to keep going.

31. Went to college, but still I do not have a job. When workmens' compensation came to an end they cut you off and they don't give a damn about you, and have not done a follow up since they cut ties with me. The people who make money off my accident, are doctors, lawyers 
and counselors. They are the only ones who keep their jobs going. And as of this date 3-15-91 I have not gotten one red cent nor help of any kind to be a productive worker for myself or my family. 4-1/2 Years on workmens' comp my bill was over $\$ 400,000$ dollars. I got less than $\$ 5,000$ for my down fall and have seen over 31 doctors. Rehabilitation said, "Go get on welfare and food stamps because no one in their right mind will hire me because of my injury." As of this date, I still don't have a job.

32. I went to work prior to your period but this might help. Your program needs a great deal of help and work or a whole new staff that knows something or anything about anything.

33. Since my operation in Feb, 1989, the doctors have discovered that my left knee is gone and that my right leg is now injured due to the left leg. In other words, after 11 years, I've worn out my right leg.

34. After starting the training I could not stand the fumes I would have to breath. Different types of fumes. Each day I would come home bleary eyed. I liked the very good help and assistance I got. I also worked hard and got top grades. As a everyday job I could not Justify the health hazards compared to pay.

35. OJT \& PCC: training Jobs (1) Touch Control, Beaverton 9 months then went out of business. (2) Jensen Display, Portland. Fired.

36. No one will hire me because I'm injured, I have not been able to obtain full time job since 3-89. Everyone that knows, tells me "not hiring" even though others have been hired.

37. My marriage has been slowly deteriorating, due to my inability to obtain job. Due to forestry cut backs won't hire, no exceptions and my attitude due to my injury.

38. Have worked steady full time since release. Job shows no sign of terminating. Started at $\$ 25 \mathrm{k}$ annually. Am now earning $\$ 37.5 \mathrm{~K}$ annually.

40. It has been awhile since my injury, but I still feel the effects financially and physically. What I received in pay off benefits was helpful, but I certainly lost a lot (family, home, lifestyle, etc.). The compensation system is cut and dried, but still there are these asses (lawyers \& appeals judges) who lead you to 
believe they are there to help make you whole. It's a B.S. system. 
APPENDIX C

WAGE HISTOGRAMS 


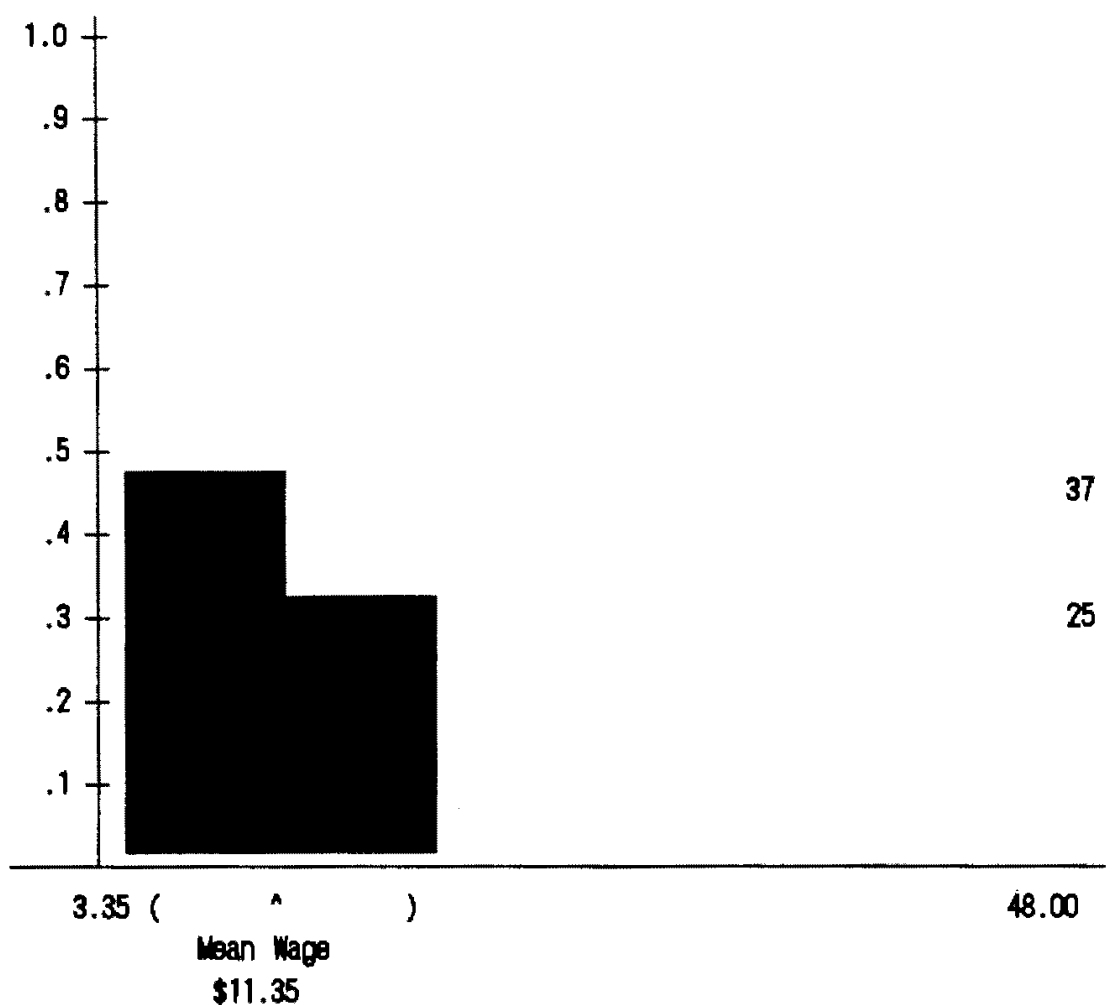

DISTRIBUTION : WAGE-AT-INJURY

5 cases with missing values excluded from plot 


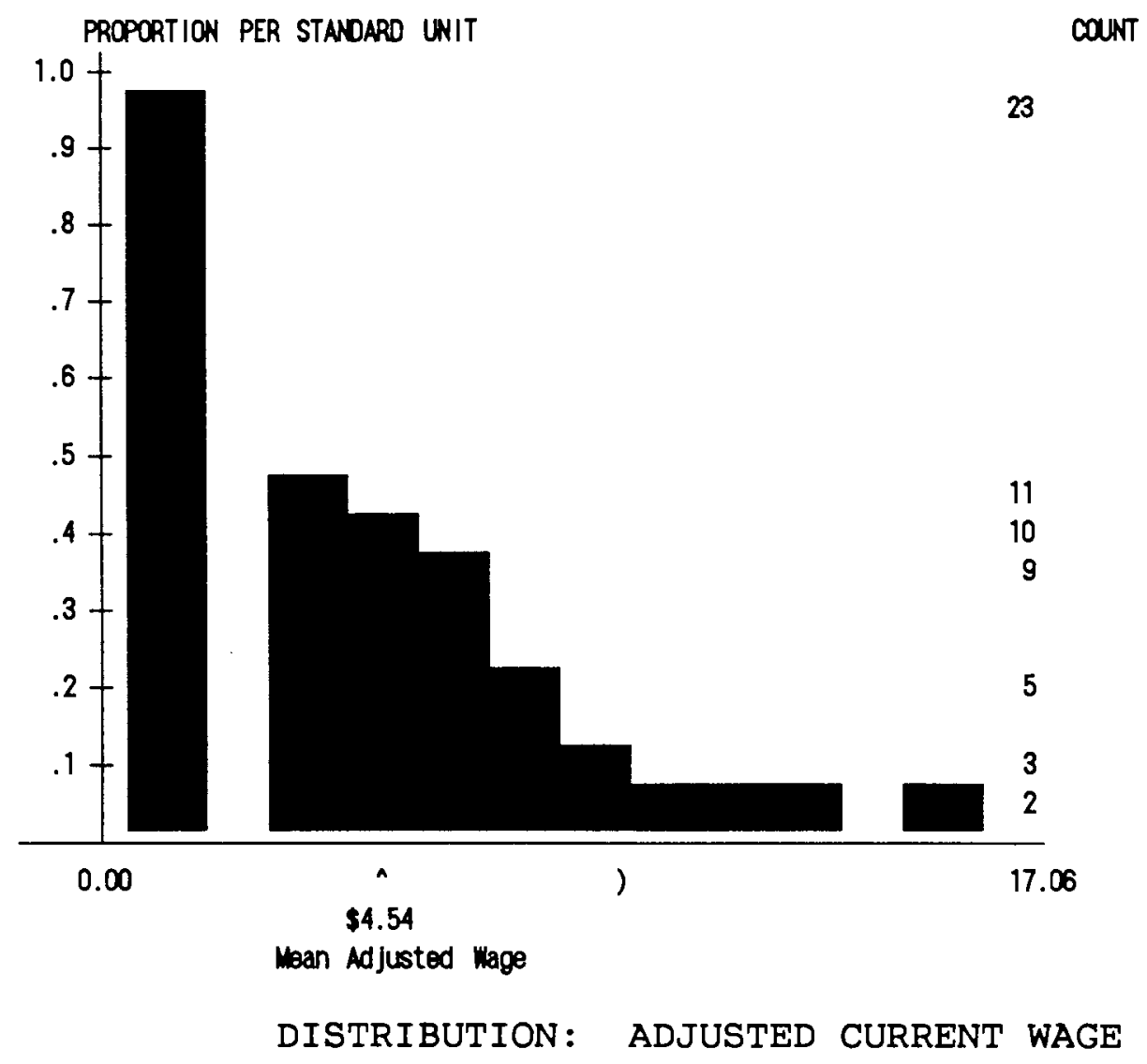

TOTAL OBSERVATIONS:

73

NOTE: \$4.54 mean wage reflects all respondents employed and unemployed. Mean adjusted wage of workers currently employed is $\$ 6.76$. 
APPENDIX D

COMPARISON OF TRAINING TO JOB IN WHICH RESPONDENTS ARE CURRENTLY ENGAGED 
COMPARISON OF TRAINING TO JOB IN WHICH WORKER IS CURRENTLY ENGAGED

Data File: Study Report: Job

TYPE OF TRAINING

WELDER

ON-THE-JOB

CLERK/WORD_PROCESS

COST ESTIMATTOR

CLERT̄CAL

WASTE WATER

BLDG INSPECTION

PART'S_COUNTERMAN

OJT

RETAILING-UCC, ROSEBURG

VACUUM_CLEANER_REPAIR

OJT

TRY'G TO LEARN TO READ

GED

PHOTO COPIER TECH

BOOK KEEPING - TYPING

ASSOCIATES DEGREE IN BUSINESS

GRAPHIC ARTS - PRINTING

ACCOUNTING CLERK I

PHOTOCOPIER TECHNICIAN

COMPUTER TECHNICIAN

MOTEL MANAGEMENT SCHOOL

AUTO BODY PAINTING

HOTEL/MOTEL MANAGEMENT

PART \& SALES OJT

BOOKKEEP ING

FLORAL DESIGN

CLERICAL

AUTO PARTS

ACCOUNTING

MICROCOMPUTER REPAIR

LEGAL ASSISTANT

ARCHITECTURAL METALS FABRICATOR

BARTENDER

REGISTERED NURSE BSN

NEVADA GAMING SCHOOL

WASTE WATER TECH

SALES REP FOOD BROKERAGE

REAL ESTATE SCHOOL

OFFICE \& ACCOUNTING SKILLS

COPIER REPAIR TECHNICIAN

AUTO PARTS DRIVER

VACUUM CLEANER REPAIR
OBS CURRENT JOB

1192 IRON_WORKER

1024 CASHĪER/CLERK

326 TRAINING_OFFICE_WORK

902 ESTIMATOR

383 PBS_/ADMITTING_CLERK

1211 SALESS PERSON

120 BLDG_INSPECTOR

$330 \mathrm{NA}$

31 RE-MODELING

863 HOME_CARE_AID_FOR_ELDERLY

607 NA

1048 CUSTOMER_SERVICE_REP_REPAIRS

518 LONG HAŪ TRUCK DRIVER

$126 \mathrm{NA}$

293 COPIER_TECH

203 OFFICE

323 TAX PREPARER

1149 PROCESS_CAMERAMAN_TRAINEE

683 NA

1057 PHOTOCOPIER TECHNICIAN

772 TECHNICIAN

1059 MANAGER_RETIREMENT_RESIDENCE

807 PAINT_ASSISTANT

375 MAINTĒNANCE

1123 PARTS \& SALES MANAGER

1088 RETAII SALES MGMT SALES REP

1091 FLORAL_DESIGN_\&_DELIVER

662 NA

949 CLERK

20 NA

749 NA

445 MILL WORK/FORKLIFT DRIVER

724 PROCĒSS SERVER/INVESTIGATOR

1222 METAL FABRICATOR

116 BARTENDER

291 NA

79 SLOT_MACHINE_MECHANIC

634 NA

856 SALES_REP

590 NA

732 CLERICAL/SALES

484 COPIER REPAIR TECHNICIAN

596 PARTS_D̄EPARTMĒNT

17 NA 
COMPUTER REPAIR

OFFICE MACHINE REPAIR

SMALL ENGINEER REPAIR

MEDICAL/CLERICAL SECRETARY

ELECTRONIC ENGINEERING TECHNOL

ELECTRICAL COST ESTIMATING

ACCOUNTING ASSIST/DATA ENTRY

BUILDING CONSTRUCTION TECH

\section{ELECTRIC}

COMPUTER PROGRAMMING

MEDICAL TERMINOLOGY, TYPING

LANDSCAPE AND DESIGN

CAMERA PERSON

CNC PROGRAMMING

AGRIBUSINESS

TECH-DRAFTING

ELECTRONICS TECHNOLOGY

PARALEGAL

TRAVEL AGENT SCHOOL

INSPECTION

SILKSCREEN PRINTER

GAME TYPING

MEDICAL CLERK

ELECTRIC MOTOR REWINDER/SERVIC

forestry Tech

ON-THE-JOB SALES

PARTS MANAGEMENT \& SUPERVISION
746 FIELD_ENGINEER_TRAINEE

1098 COUNSËLOR

1206 NA

0 WAITRESS

136 SERVICEMAN

347 ELECTRICAL_COST_ESTIMATOR

921 DATA CLERK

1052 NA

989 MILL_SUPERVISOR

428 NA

121 NA

932 DATA_PROCESSING_COORDINATOR

1111 PATHŌLOGY/CYTOGĒNETIC

151 LANDSCAPE/MAINTENANCE

525 CAMERA PERSON/LAYOUT PERSON

665 LEADMAN $\bar{N}$ OPERATOR/PROGRAMMER

34 SALES_A

434 NA

58 BIO_MED_TECH

95 NA

373 MANAGER_GRESHAM_OFFICE

393 SPECIAL_INSPECTOR

396 NA

1071 NA

790 CANNERY

1134 CARPET_CLEANER

426 Skill Trainer

261 SALES_LOT_MGR/SVC_MGR_TRUCKS 460 SALES 


\section{APPENDIX E}

LIST OF JOBS IN WHICH RESPONDENTS ARE CURRENTLY ENGAGED 
LIST OF JOBS IN WHICH RESPONSE GROUP WORKERS ARE CURRENTLY ENGAGED

Data File: Study Report: Job

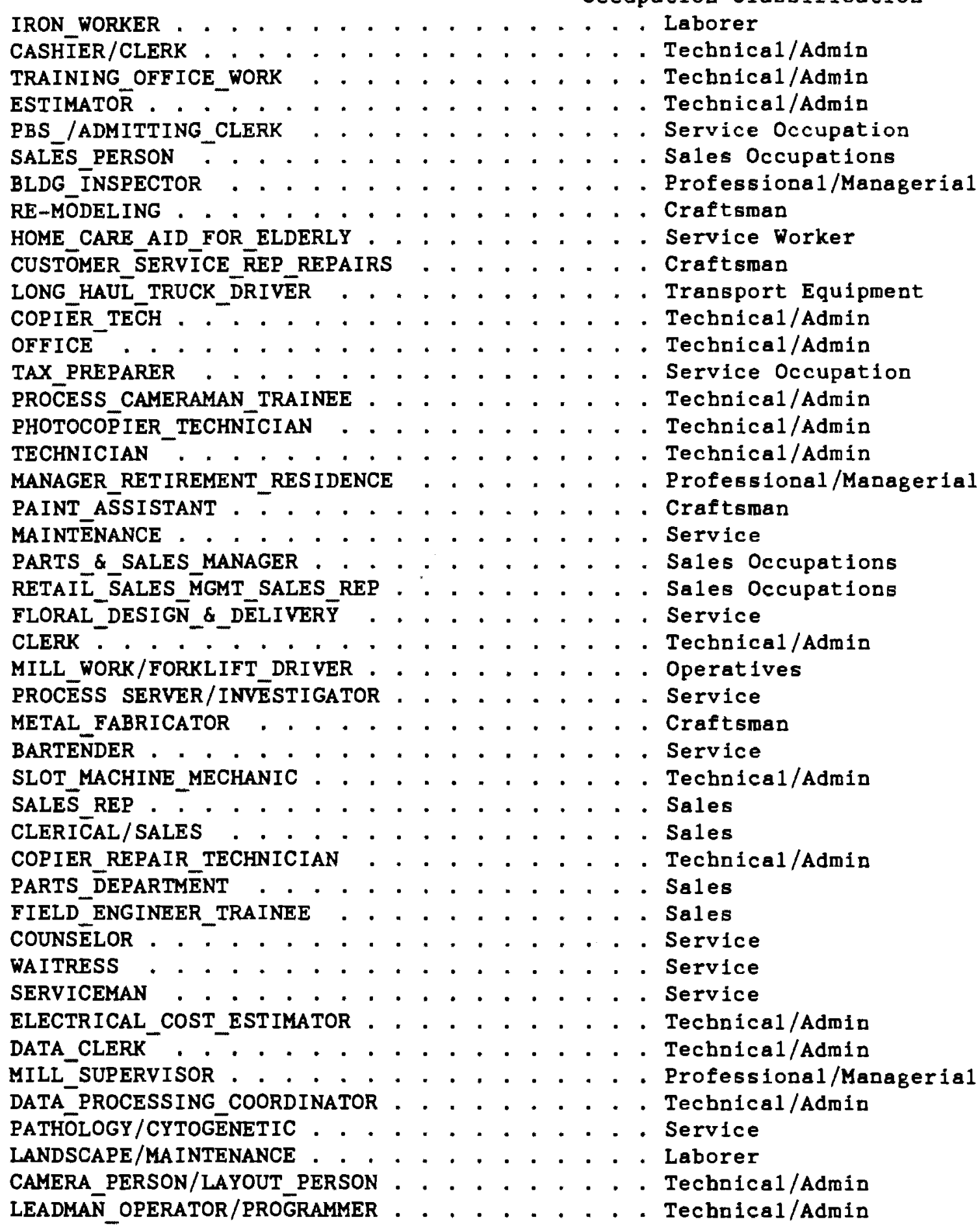




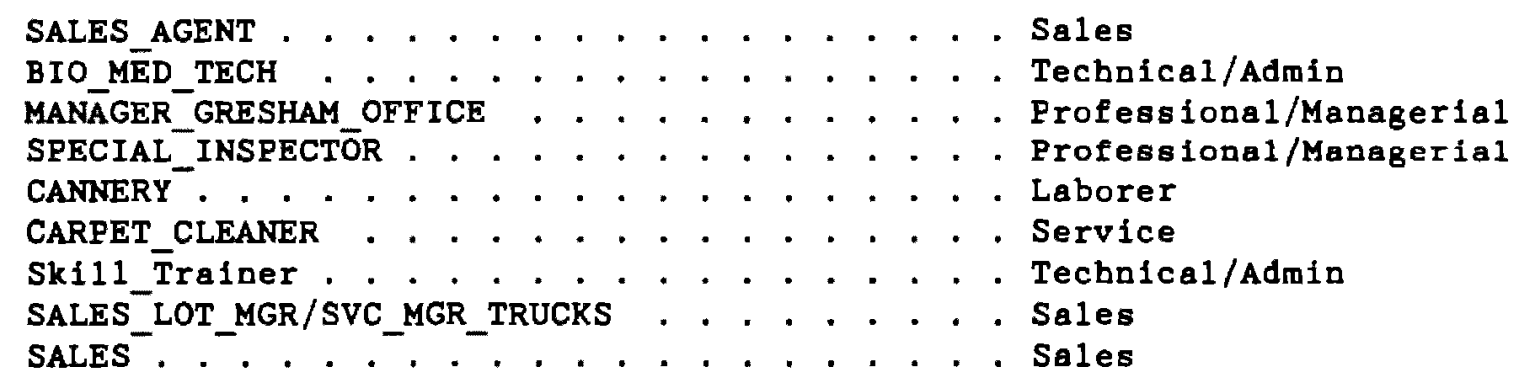

Ta11y

Laborers, except Farm . . . . . . . . . 3

Service Workers... . . . . . . . . . . 12

Operatives except Transport . . . . . . . 1

Transport Equipment Operators . . . . . . 1

Craftsmen . . . . . . . . . . . . . . . 4

Technical A Admin. Support . . . . . . . 18

Farm Workers . . . . . . . . . . . . . 0

Sales Occupations... . . . . . . . . 10

Professional \& Managerial . . . . . . . . 5

other... . . . . . . . . . . . . . 0

Total . . . . . . . . . . . . . 54 